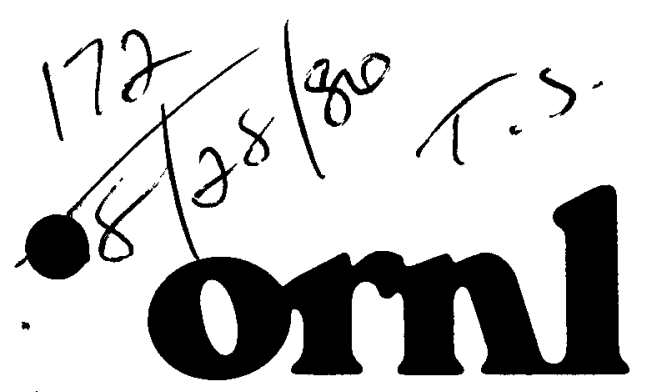

OAK

RIDGE

NATIONAL

LABORATORY

UNION

CARBIDE
MASTER

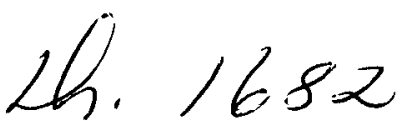

ORNL-5597

\title{
Carbon-14 Production in the Peach Bottom HTGR Core
}

\author{
R. P. Wichner \\ F. F. Dyer
}

\section{OPERATED BY}

UNION CARBIDE CORPORATION FOR THE UNITED STATES DEPARTMENT OF ENERGY 


\section{Printed in the United States of America. Available from}

National Technical Informatıon Service

U.S. Department of Commerce

5285 Port Royal Road, Springfield, Virginia 22161

NTIS price codes-Printed Copy: A05; Microfiche A01

This report was prepared as an account of work sponsored by an agency of the United States Government. Neither the United States Government nor any agency thereof, nor any of their employees, makes any warranty, express or implied, or assumes any legal liability or responsibılity for the accuracy, completeness, or usefulness of any information, apparatus, product, or process disclosed, or represents that its use would not infringe privately owned rights Reference herein to any specific commercial product, process, or service by trade name, trademark. manufacturer, or otherwise, does not necessarily constitute or imply its endorsement. recommendation, or favoring by the United States Government or any agency thereof The views and opınions of authors expressed herein do not necessarily state or reflect those of the United States Government or any agency thereof 


\section{DISCLAIMER}

This report was prepared as an account of work sponsored by an agency of the United States Government. Neither the United States Government nor any agency Thereof, nor any of their employees, makes any warranty, express or implied, or assumes any legal liability or responsibility for the accuracy, completeness, or usefulness of any information, apparatus, product, or process disclosed, or represents that its use would not infringe privately owned rights. Reference herein to any specific commercial product, process, or service by trade name, trademark, manufacturer, or otherwise does not necessarily constitute or imply its endorsement, recommendation, or favoring by the United States Government or any agency thereof. The views and opinions of authors expressed herein do not necessarily state or reflect those of the United States Government or any agency thereof. 


\section{DISCLAIMER}

Portions of this document may be illegible in electronic image products. Images are produced from the best available original document. 


\section{ORNL-5597}

Dist. Category UC-77

Contract No. W-7405-eng-26

CHEMICAL TECHNOLOGY DIVISION

HTGR BASE TECHNOLOGY PROGRAM

HTGR Chemistry Studies (189a 01329)

CARBON-14 PRODUCTION IN THE PEACH BOTTOM HTGR CORE

R. P. Wichner

F. F. Dyer*

Date Published - July 1980

*Analytical Chemistry Division.

This bock was prepdred as an account of work sponsored by an agency of the United States Government
Neither the United Sates Government nur any and worranty, express or umplied or assurnes any legal labulity ar responer employees makes any completeness or usefulness of any information agoaratus product or process discloseddcy represents that its use would not nfringe privately owned rights Reference herem to anr soef no: necer product process or service by trade namie trademark monufacturer or otherwise does

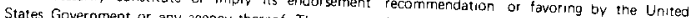
necessarily state or reflecr agne of thereor The vews and opinions of duthors expressed herein do not

OAK RIDGE NATIONAL LABORATORY

Oak Ridge, Tennessee 37830

operated by

UNION CARBIDE CORPORATION

for the

DEPARTMENT OF ENERGY 
- 


\section{CONTENTS}

Page

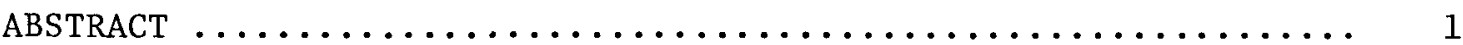

1. INTRODUCTION $\ldots \ldots \ldots \ldots \ldots \ldots \ldots \ldots \ldots \ldots \ldots \ldots \ldots \ldots \ldots \ldots \ldots$

1.1 Objectives and Scope $\ldots \ldots \ldots \ldots \ldots \ldots \ldots \ldots \ldots \ldots \ldots \ldots \ldots$

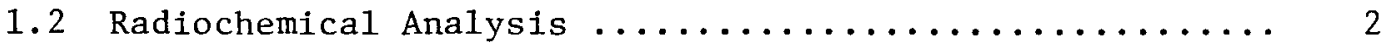

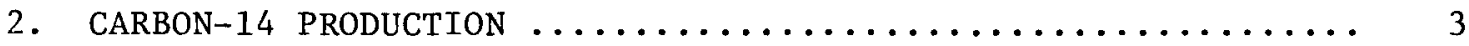

2.1 Neutron Reactions and Cross Sections $\ldots \ldots \ldots \ldots \ldots \ldots \ldots$

2.2 Average Neutron Flux $\ldots \ldots \ldots \ldots \ldots \ldots \ldots \ldots \ldots \ldots \ldots \ldots$

3. INVENTORY IN CORE COMPONENTS $\ldots \ldots \ldots \ldots \ldots \ldots \ldots \ldots \ldots \ldots \ldots \ldots$

3.1 Distribution in the Sleeves and Spines $\ldots \ldots \ldots \ldots \ldots \ldots 10$

3.2 Inventory in the sleeves and Spines $\ldots \ldots \ldots \ldots \ldots \ldots \ldots$

3.3 Inventory and Distribution in the Fuel Element Fission

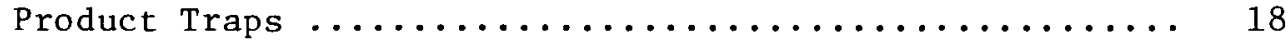

3.4 Inventory in the Fue1 $\ldots \ldots \ldots \ldots \ldots \ldots \ldots \ldots \ldots \ldots \ldots \ldots$

3.5 Inventory in the Removable Radial Reflector ........ 22

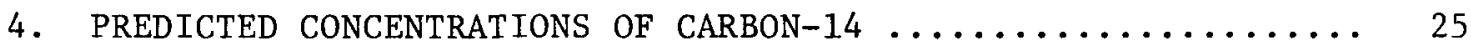

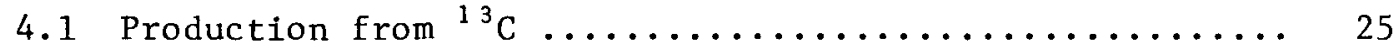

4.2 Surface Concentration Peaks in the Sleeves and Spines .. 30

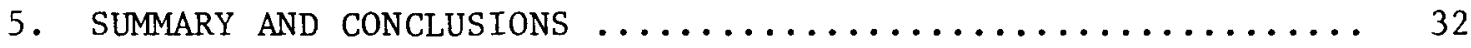

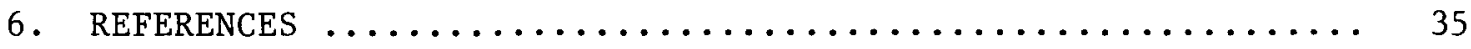

Appendix. MEASURED RADIAL CONCENTRATION DISTRIBUTIONS OF ${ }^{14} \mathrm{C}$ IN FUEL ELEMENT SLEEVES AND SPINES 


\section{CARBON-14 PRODUCTION IN THE PEACH BOTTOM HTGR CORE}

R. P. Wichner

F. F. Dyer

\section{ABSTRACT}

Carbon-14 concentrations were measured in a variety of core components during the Peach Bottom Surveillance Program. Five fuel element sleeves and spines were dissected to obtain radial concentration profiles at four axial locations. The profiles show that the major part of the ${ }^{14} \mathrm{C}$ in these graphite components characteristically showed a flat radial distribution across the interior of the member; the balance was found in concentration peaks at each exposed surface. The source of these surface peaks is not fully understood.

Concentrations were also determined in five fuel element fission product traps, one removable radial reflector block, and 12 fuel particle pairs taken from a number of axial locations in one fuel element. Estimates of whole-core inventory were made from these concentration determinations. Most surprising was the comparatively high ${ }^{14} \mathrm{C}$ inventory assoctated with fuel particles, which must be ascribed to nitrogen contamination of the fuel. Also unexpectedly high was the level found in the fuel element charcoal traps, which despite their small mass contained almost as much ${ }^{1{ }^{4}} \mathrm{C}$ as all the graphite sleeves and spines. On a per unit energy basis, an estimated $113 \mathrm{Ci} /$ GW( $t)-y r$ of ${ }^{14} \mathrm{C}$ was produced in the Peach Bottom HTGR, which is about $30 \%$ higher than predictions based on the ORIGEN computer code. The difference seems due mainly to the assumed level of nitrogen contamination in the fuel.

\section{INTRODUCTION}

\subsection{Objectives and Scope}

The first objective of this study was to bring together the diverse ${ }^{14} \mathrm{C}$ concentration measurements performed on Peach Bottom HTGR core components during the surveillance program for this reactor. The Peach Bottom Surveillance Program was active at ORNL from 1971 through 1977, during which time radioactivity scans were performed on the primary circuit. In 
addition, plate-out probes, designed to distinguish between various forms of fission product activity, were installed in the primary circuit and examined periodically. These and various other primary circuit measurements are described in ref. 1. Most of the surveillance activities, however, were related to the postirradiation examination of a carefully selected series of six fuel elements; the results of these measurements are described in published examinations reports. ${ }^{2-7}$ Carbon-14 concentrations were determined in the graphite sleeves and spines and in the charcoal traps of five of these six elements. ${ }^{3-7}$ In addition, ${ }^{14} \mathrm{C}$ levels were determined in the fuel of one element and throughout one removable radial reflector element.

A second objective of this task was to integrate these measurements to determine whole-core inventories of ${ }^{14} \mathrm{C}$. Sufficient concentration profile data are available for this purpose for the graphite fuel element components and for the charcoal fission product traps; however, because the fuel of only one element and only one radial reflector block were examined, extrapolation of these observations to whole-core values is somewhat more uncertain. Nevertheless, the derived inventories are based on observation and are therefore more positive than earlier, conjectural estimates. The principal benefit of this study, derived from this direct core-wide inventory determination, may be a more confident prediction of ${ }^{14} \mathrm{C}$ levels in future HTGR cores, which would influence the design of the fuel reprocessing system.

\subsection{Radiochemica1 Analysis}

The radiochemical method used to measure beta-emitting radionuclides in Peach Bottom graphite is summarized briefly in ref. 3. For completeness, the determination of ${ }^{14} \mathrm{C}$ is recapitulated below.

Carbon-14 was measured by counting the 156-keV beta particle using a liquid scintillation procedure. Both the fuel particles and graphite samples were burned in moist oxygen, and the $\mathrm{CO}_{2}$ was collected in methyl alcohol containing the hydroxide of Hyamine $10-\mathrm{X}$ at a concentration of

$1 \underline{\mathrm{N}}$. Because tritium content was determined in the same samples in which 
${ }^{14} \mathrm{C}$ was measured (see ref. 8), water vapor was introduced into the oxygen stream to promote the capture of HTO in a cold trap. The moisture, however, was removed before the $\mathrm{CO}_{2}$ and thus did not represent a potential difficulty with the measurement of ${ }^{14} \mathrm{C}$. After the $\mathrm{CO}_{2}$ was captured, a known aliquot of the Hyamine solution was introduced directly into a small volume of a liquid scintillator, and the ${ }^{14} \mathrm{C}$ was counted. Standard specimens containing known quantities of ${ }^{14} \mathrm{C}$ were analyzed similarly so that activities could be derived from the count rate data.

\section{CARBON-14 PRODUCTION}

\subsection{Neutron Reactions and Cross Sections}

The neutron reactions that produce ${ }^{14} \mathrm{C}$ in reactors have been summarized by Davis. ${ }^{9}$

1. ${ }^{13} \mathrm{C}(\mathrm{n}, \gamma){ }^{14} \mathrm{C}$. The cross section for this reaction with $0.025-\mathrm{eV}$ neutrons is given ${ }^{10}$ as $0.9 \mathrm{mb}$ with a resonance integral value of $1.3 \mathrm{mb}$. Reference 10 lists a standard deviation of $\pm 20 \%$ for the thermal cross section, and values above thermal are evidently far more uncertain. This reaction is not listed in the $\mathrm{END} / \mathrm{F}-\mathrm{IV}$ file.

2. ${ }^{14} \mathrm{~N}(n, p){ }^{14} \mathrm{C}$. Cross sections for this reaction as a function of neutron energy are known with much more certainty than for reaction 1 . Reference 10 lists a value of $1.81 \mathrm{~b}$ with a precistion of $\pm 3 \%$ for $0.025-\mathrm{eV}$ neutrons. The cross-section dependence on neutron energy, as tabulated in the END/F-IV file, is illustrated in Fig. 2.1.

3. ${ }^{15} \mathrm{~N}\left(\mathrm{n}, \mathrm{n}^{\prime} \mathrm{p}\right){ }^{14} \mathrm{C}$. The END/F-IV file lists the threshold for this reaction as $10.89 \mathrm{MeV}$. Therefore, the effective value for an HTGR core would be zero.

4. ${ }^{15} \mathrm{~N}(\mathrm{n}, \mathrm{d}){ }^{14} \mathrm{C}$. The END/F-IV file lists an $8.52-\mathrm{MeV}$ threshold for this reaction. Therefore, this too would be insignificant in an HTGR core.

5. ${ }^{16} \mathrm{O}\left(\mathrm{n},{ }^{3} \mathrm{He}\right)^{14} \mathrm{C}$. Though very 1 ittle information exists for this reaction, its highly endothermic nature $(-14.6 \mathrm{MeV})$ indicates that it would probably be insignificant in an HTGR core. 


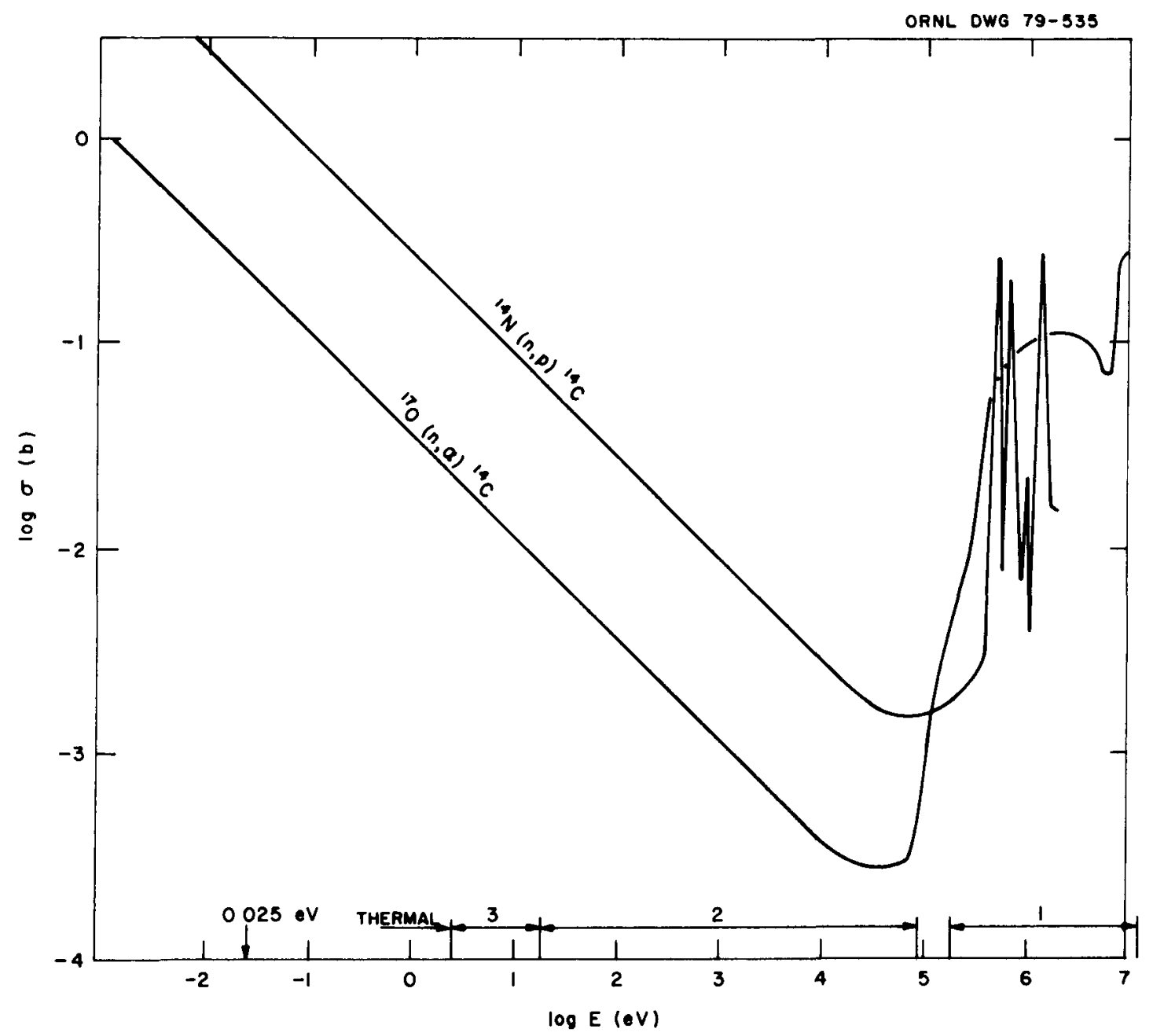

Fig. 2.1. Cross sections of reactions ${ }^{14} \mathrm{~N}(n, p){ }^{14} \mathrm{C}$ and ${ }^{17} \mathrm{O}(\mathrm{n}, \alpha){ }^{14} \mathrm{C}$ as a function of neutron energy. 
6. ${ }^{17} \mathrm{O}(\mathrm{n}, \alpha)^{14} \mathrm{C}$. Reference 10 lists a $0.235-\mathrm{b}$ value for $0.025-\mathrm{eV}$ neutrons with a $\pm 4 \%$ standard deviation. The resonance integral is given as $0.105 \mathrm{~b}$ with $\mathrm{a} \pm 10 \%$ uncertainty. Figure 2.1 illustrates the energy dependence as listed in the END/F-IV file.

Table 2.1 summarizes the pertinent information regarding neutron reactions that produce ${ }^{14} \mathrm{C}$ in HTGRs. In sect. 4, measured ${ }^{14} \mathrm{C}$ concentrations are compared with predictions based on flux levels and the crosssection values listed above.

\subsection{Average Neutron F1ux}

Neutron fluxes during core 2 operation have been reported as a function of time in a series of correspondences ${ }^{11}$ for four fuel element locations - E06-01, E11-07, E14-01, and F03-01. In addition, f1uxes at location E06-01 are reported in the postirradiation examination report ${ }^{12}$ for fuel test element 18, which occupied that location from the time of removal of the fuel element at 252 equivalent full-power days (EFPD) to end of life (EOL). All flux levels are reported as average values over the active length of the fuel element. Time- and space-averaged fluxes for each of the four energy groups employed were obtained by averaging the reported fluxes at these four locations over the operating time for core 2. These values are listed in Table 2.2. The actual operating time for core 2 was 1070 days out of a total span (including shutdowns) of 1550 days, for an on-stream factor of $69 \%$. The 1070 operating days yielded a total of 897 EFPD based on a design rating of $115 \mathrm{MW}(\mathrm{t})$.

A typical HTGR flux spectrum is given in Table 2.3 and Fig. 2.2. These values were calculated by Thomas $^{13}$ for a large HTGR with $\mathrm{C} / \mathrm{U}=3000$ and $\mathrm{C} / \mathrm{Th}=240$ in its $20 \mathrm{th}$ reload cycle. In comparison, the second Peach Bottom core had a loaded $\mathrm{C} / \mathrm{U}$ of 2260 and $\mathrm{C} / \mathrm{Th}$ of 320 , which is sufficiently close to the case assumed by Thomas to allow its use for rough estimation of ${ }^{14} \mathrm{C}$ buildup.

Comparison of the cross section dependence on energy of reactions ${ }^{14} \mathrm{~N}(\mathrm{n}, \mathrm{p}){ }^{14} \mathrm{C}$ and ${ }^{17} \mathrm{O}(\mathrm{n}, \alpha){ }^{14} \mathrm{C}$, shown in Fig. 2.1, with the neutron energy spectrum indicates that the major ${ }^{14} \mathrm{C}$ production from these reactions 
Table 2.1. Neutron reactions producing ${ }^{14} \mathrm{C}$

\begin{tabular}{|c|c|c|c|}
\hline Reaction & $\begin{array}{l}\text { Cross section with } \\
0.025-\mathrm{eV} \text { neutrons } \\
\text { (b) }\end{array}$ & $\begin{array}{l}\text { Resonance integral } \\
\text { (b) }\end{array}$ & $\begin{array}{c}\text { Average cross section used } \\
\text { with ORIGEN } \\
\text { (b) }\end{array}$ \\
\hline${ }^{13} \mathrm{C}(\mathrm{n}, \gamma){ }^{14} \mathrm{C}$ & $9.0 \times 10^{-4} \pm 2.0 \times 10^{-4}$ & $1.3 \times 10^{-4} \pm 2.0 \times 10^{-4}$ & $4.19 \times 10^{-4}$ \\
\hline${ }^{14} \mathrm{~N}(\mathrm{n}, \mathrm{p}){ }^{14} \mathrm{C}$ & $1.81 \pm 0.05$ & $c$ & 1.02 \\
\hline${ }^{15} \mathrm{~N}\left(\mathrm{n}, \mathrm{n}^{\prime} \mathrm{p}\right){ }^{14} \mathrm{C}$ & $0^{d}$ & $c$ & 0 \\
\hline${ }^{15} \mathrm{~N}(\mathrm{n}, \mathrm{d}){ }^{14} \mathrm{C}$ & $0^{e}$ & $c$ & 0 \\
\hline${ }^{16} \mathrm{O}\left(\mathrm{n},{ }^{3} \mathrm{He}\right){ }^{1{ }^{4} \mathrm{C}}$ & $f$ & $f$ & 0 \\
\hline${ }^{17} \mathrm{O}(\mathrm{n}, \alpha){ }^{14} \mathrm{C}$ & $0.235 \pm 0.010$ & $0.105 \pm 0.010$ & 0.110 \\
\hline
\end{tabular}

a Source: S. F. Maghabghab and D. I. Garber, Neutron Cross Section Vol. I, Resonance Parameters, 3d ed., BNL 325 (June 1973).

$b_{\text {Source: }}$ W. Davis, Jr., "Carbon-14 Production in Nuclear Reactors," in Management of Low-Level Radioactive Waste, vol. I, M. W. Carter et al., Eds., Pergamon Press, 1979.

${ }^{c}$ Not given.

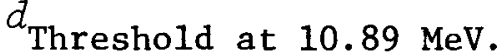

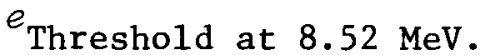

$f_{\text {Not }}$ given, but probably zero. 
Table 2.2. Average fluxes of four groups during core 2 operation

\begin{tabular}{llc}
\hline & Energy range & $\begin{array}{c}\text { Average flux } \\
\left(\mathrm{n} / \mathrm{cm}^{2} \cdot \mathrm{s}\right)\end{array}$ \\
\hline$\phi_{1}$ & $0.18-14.96 \mathrm{MeV}$ & $3.28 \times 10^{13}$ \\
$\phi_{3}$ & $17.6 \mathrm{eV}-86.5 \mathrm{keV}^{b}$ & $6.32 \times 10^{13}$ \\
$\phi_{\mathrm{th}}$ & $2.38-17.6 \mathrm{eV}$ & $1.04 \times 10^{13}$ \\
\hline
\end{tabular}

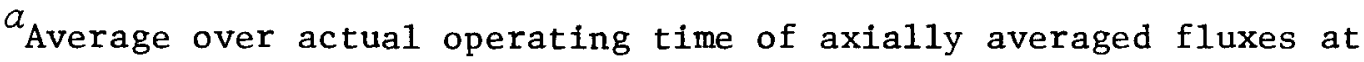
locations E06-01, E11-07, E14-01, and F03-01.

$b_{A}$ gap in energy between groups 1 and 2 occurs in most of the available records of Peach Bottom fluxes. This appears to have been caused by the desire of materials analysts to record the 0.18 - to $14.96-$ $\mathrm{MeV}$ range to correlate with irradiation test data and the failure to note the subsequent gap in the spectrum. This gap has no significance as far as ${ }^{14} \mathrm{C}$ production is concerned. 
Table 2.3. Typical HTGR flux spectrum ${ }^{\alpha}$

\begin{tabular}{|c|c|c|c|c|}
\hline Group & \multicolumn{2}{|c|}{$\begin{array}{l}\text { Energy range } \\
(\mathrm{eV})\end{array}$} & $\begin{array}{l}\text { Average energy } \\
(\mathrm{eV})\end{array}$ & $\begin{array}{c}\phi(\mathrm{E}) \\
\left(\mathrm{n} / \mathrm{cm}^{2} \cdot \mathrm{s} \cdot \mathrm{eV}\right)\end{array}$ \\
\hline 1 & $2.02 \times 10^{6}$ & $14.9 \times 10^{6}$ & $8.46 \times 10^{6}$ & $6.43 \times 10^{5}$ \\
\hline 2 & $4.98 \times 10^{5}$ & $2.02 \times 10^{6}$ & $1.26 \times 10^{6}$ & $1.72 \times 10^{7}$ \\
\hline 3 & $1.11 \times 10^{5}$ & $4.98 \times 10^{5}$ & $3.05 \times 10^{5}$ & $6.56 \times 10^{7}$ \\
\hline 4 & $2.48 \times 10^{4}$ & $1.11 \times 10^{5}$ & $6.79 \times 10^{4}$ & $2.61 \times 10^{8}$ \\
\hline 5 & $5.53 \times 10^{3}$ & $2.48 \times 10^{4}$ & $1.52 \times 10^{4}$ & $1.13 \times 10^{9}$ \\
\hline 6 & $1.23 \times 10^{3}$ & $5.53 \times 10^{3}$ & $3.38 \times 10^{3}$ & $4.91 \times 10^{9}$ \\
\hline 7 & 167 & $1.23 \times 10^{3}$ & 699 & $2.52 \times 10^{10}$ \\
\hline 8 & 47.9 & 167 & 108 & $1.28 \times 10^{11}$ \\
\hline 9 & 13.7 & 47.9 & 30.8 & $3.98 \times 10^{11}$ \\
\hline 10 & 5.04 & 13.7 & 9.37 & $1.10 \times 10^{12}$ \\
\hline 11 & 1.86 & 5.04 & 3.45 & $2.80 \times 10^{12}$ \\
\hline 12 & 0.881 & 1.86 & 1.37 & $7.79 \times 10^{12}$ \\
\hline 13 & 0.249 & 0.881 & 0.565 & $3.78 \times 10^{14}$ \\
\hline 14 & 0.0823 & 0.249 & 0.166 & $1.94 \times 10^{14}$ \\
\hline 15 & 0.06 & 0.0823 & 0.0711 & $1.35 \times 10^{15}$ \\
\hline
\end{tabular}

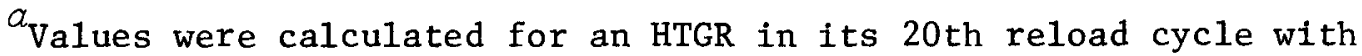
$\mathrm{C} / \mathrm{U}=3000$ and $\mathrm{C} / \mathrm{Th}=240$.

Source: W. E. Thomas, Engineering Technology Division, ORNL, personal communication, 1978 . 


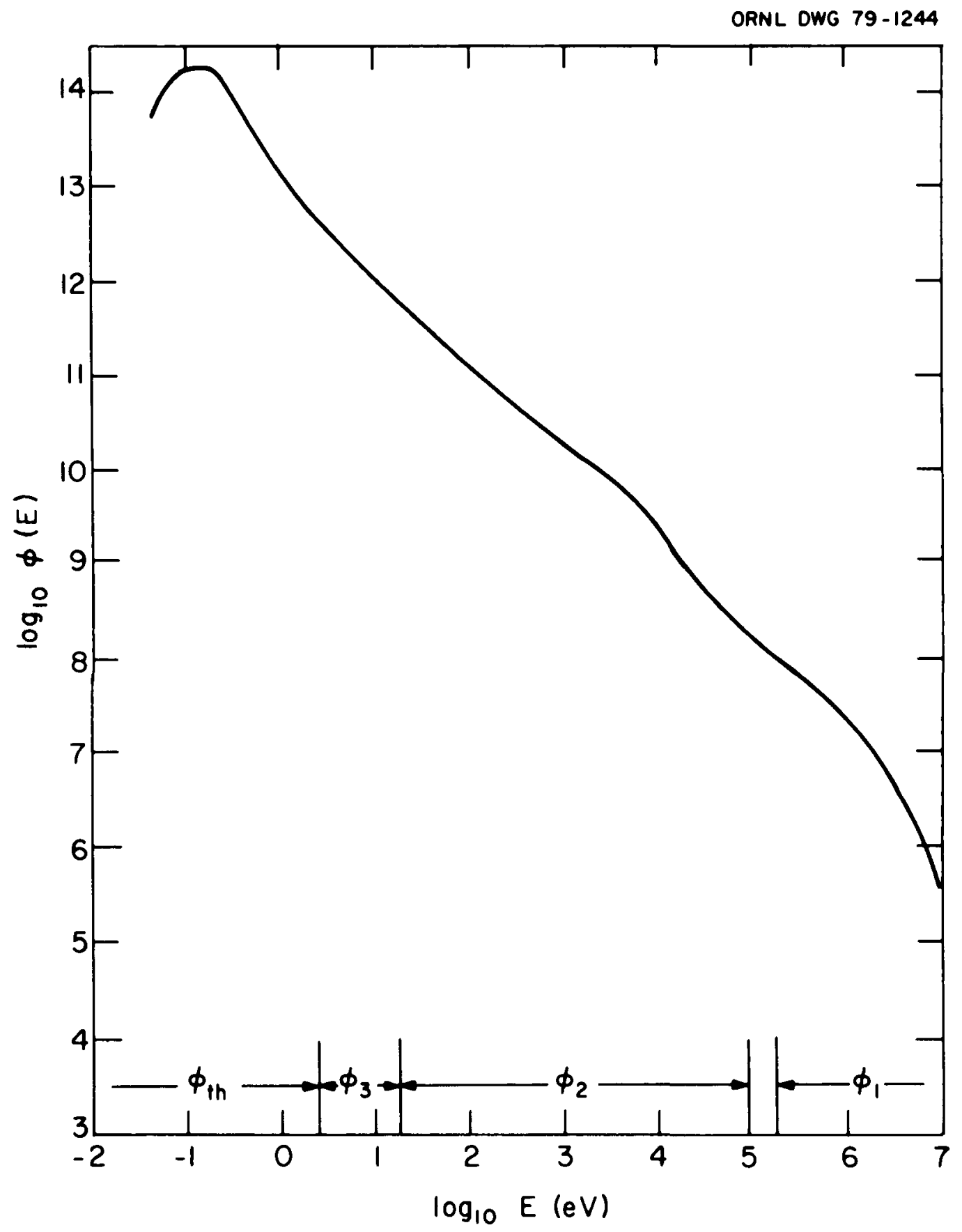

Fig. 2.2. HTGR flux spectrum. Source: F. F. Dyer et al., Distribution of Fission Products in Peach Bottom HTGR Fuel EZement F03-01, ORNL/TM-5996 (June 1978). 
occurs with the thermal neutron group. Although cross section data for the ${ }^{13} \mathrm{C}(\mathrm{n}, \gamma)^{14} \mathrm{C}$ reaction is much sparser, presumably the same conclusion also applies.

\section{INVENTORY IN CORE COMPONENTS}

\subsection{Distribution in the Sleeves and Spines}

Carbon-14 concentrations were measured in the graphite sleeves and spines of five fuel elements during the course of the Peach Bottom Surveillance Program, which was active from 1971 through 1977. These data, abstracted from the fuel element postirradiation examination reports, ${ }^{3-7}$ are presented in the Appendix in Tables A.1 through A.35. Table 3.1 summarizes the scope of the data that appears in the Appendix.

As noted in Table 3.1, concentrations were obtained in fuel elements E11-07, E14-01, F03-01, E01-01, and F03-01. Of these, the first was removed after 701 EFPD of irradiation (out of 897), while the remainder are EOL elements. Radial concentration distributions were obtained in the sleeves and spines of these fuel elements at the axial locations designated in Table 3.1. Full descriptions of these fuel elements, as well as the manner in which the radial profile data were acquired, are provided in the examination reports. ${ }^{2-7}$

Two typical sets of radial profiles, those for the E11-07 sleeve and spine, are illustrated in Figs. 3.1 and 3.2. We note here that typically the radial profiles in the central graphite portions are flat, with concentration peaks observed near each surface. This characteristic profile suggests that the interior, radially flat portion is due to a combination of the reaction ${ }^{13} \mathrm{C}(\mathrm{n}, \gamma){ }^{14} \mathrm{C}$ together with neutron reactions with a uniform air deposit, via ${ }^{14} \mathrm{~N}(n, p){ }^{14} \mathrm{C}$ and ${ }^{17} \mathrm{O}(\mathrm{n}, \alpha){ }^{14} \mathrm{C}$. A1though graphite soon after manufacture is clearly free of adsorbed nitrogen and oxygen due to high firing temperatures, prolonged exposure to air prior to reactor operation probably resulted in a uniform deposit of adsorbed oxygen and nitrogen, which would contribute to the flat profile observed away from the surfaces. 
Table 3.1. Directory of tabulated and graphical radial distribution data presented in the Appendix

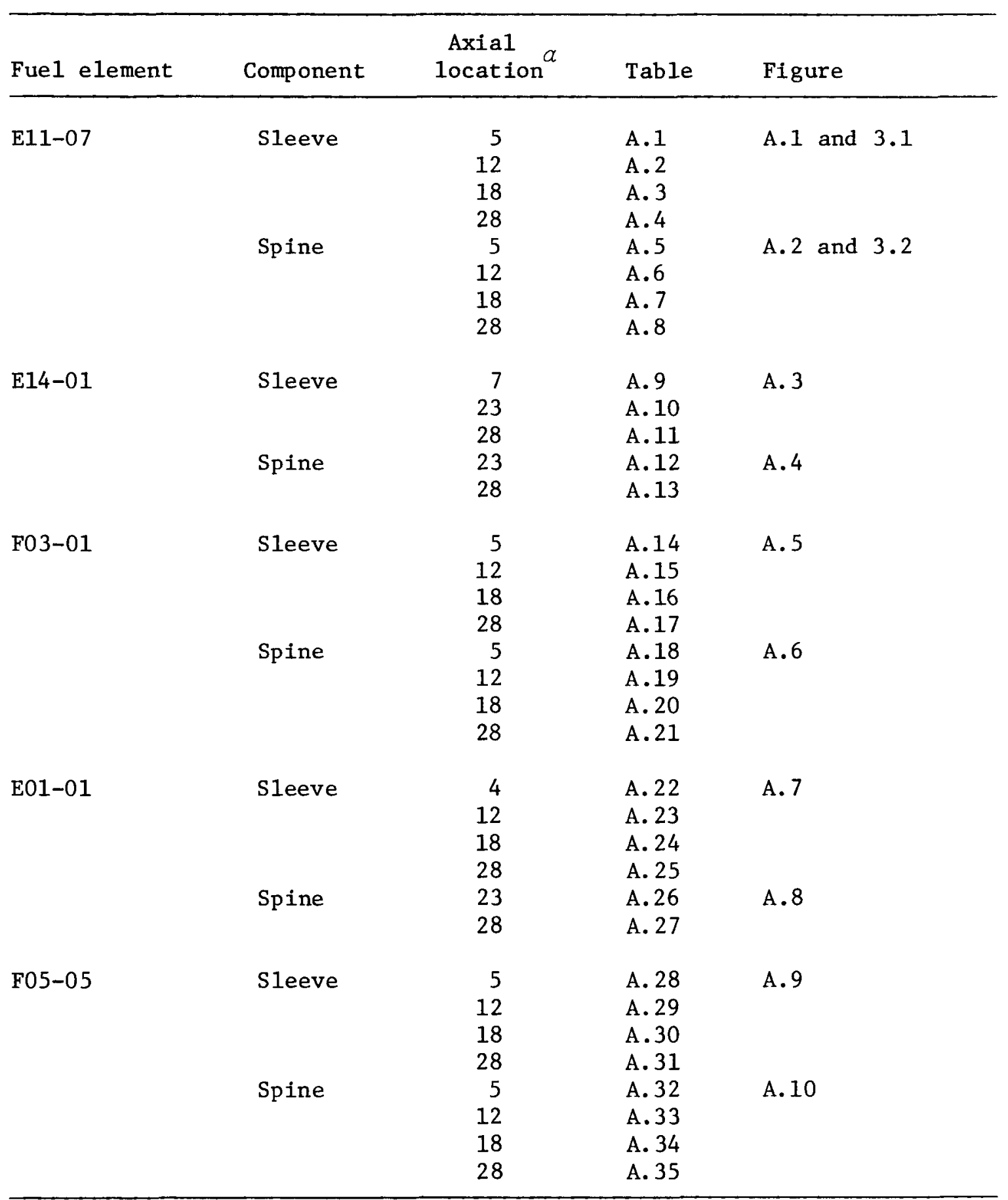

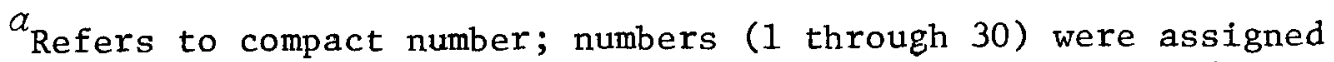
from bottom to top of fuel element. Each compact was $7.62 \mathrm{~cm}$ (3.00 in.) long prior to irradiation. 


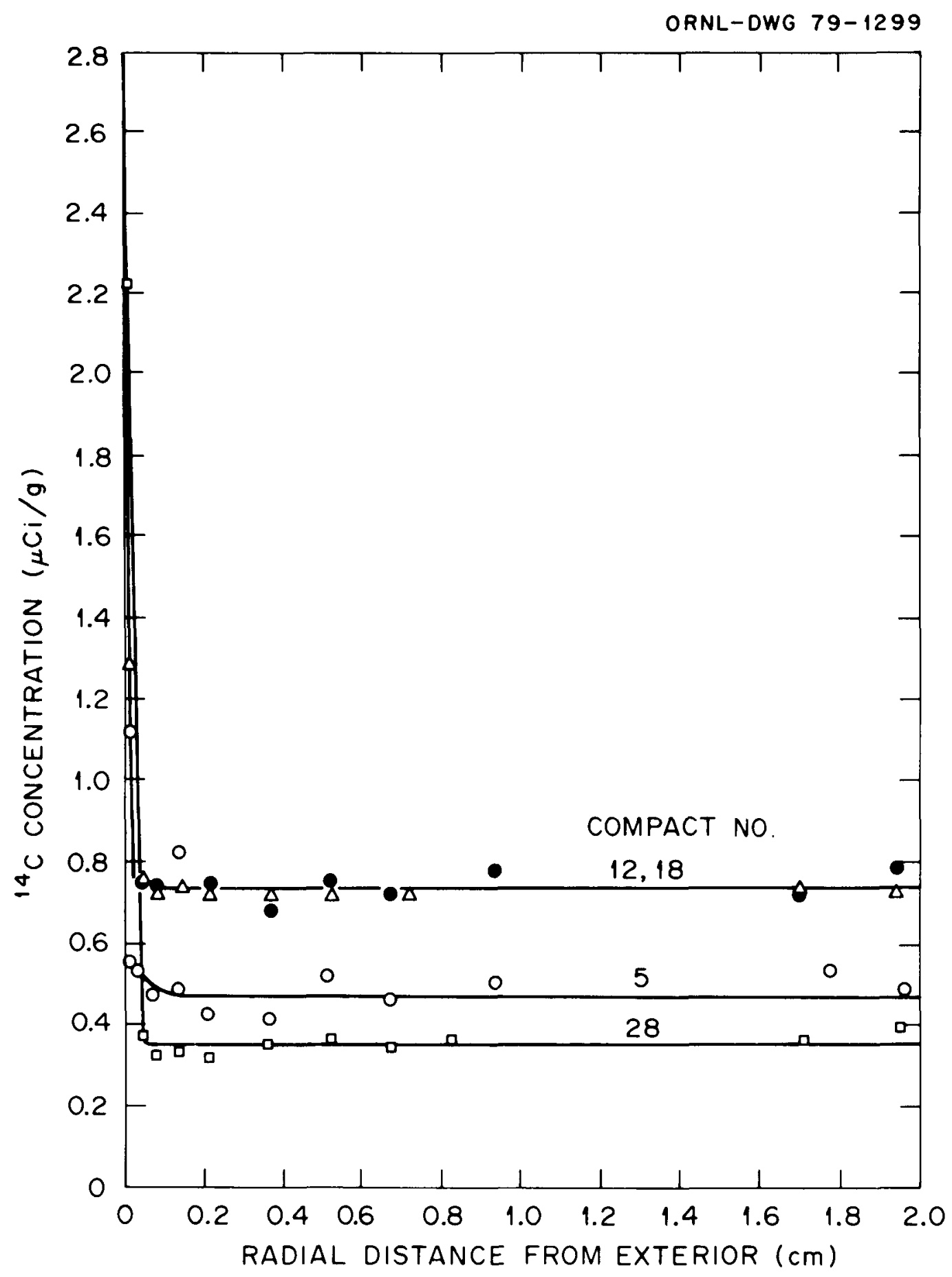

Fig. 3.1. Distribution of ${ }^{14} \mathrm{C}$ in fuel element sleeve at compact Nos. $5,12,18$, and 28 of fuel element E11-07. 


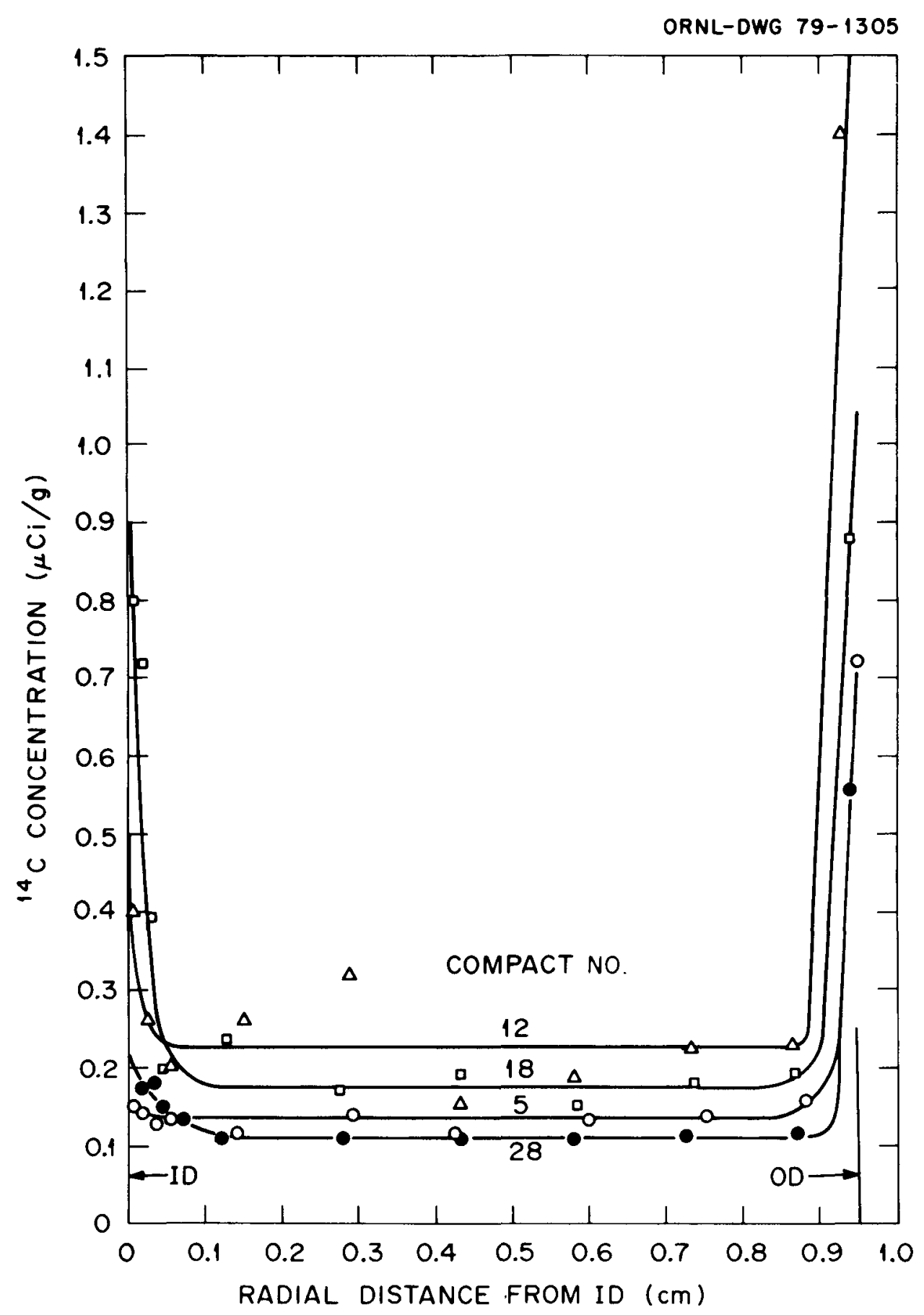

Fig. 3.2. Distribution of ${ }^{14} \mathrm{C}$ in fuel element spine at compact Nos. $5,12,18$, and 28 of fuel element E11-07. 
Further evidence that neutron reactions with both ${ }^{13} \mathrm{C}$ and air contributed to the flat portion of the profile is afforded by the observation that ${ }^{14} \mathrm{C}$ concentrations in the interior part of the spines are consistently higher than those in the interior of the sleeves (by a factor of about 3). This may be seen in Fig. 3.3, where these concentrations are plotted as a function of axial location (compact number) for the five fuel elements on which measurements were made. There appears to be no other reasonable explanation for the higher concentrations observed in the spines other than the presumption that the spines possessed initially higher levels of adsorbed air than the sleeves. This is explored more fully in Sect. 4.1, where reaction rates based on cross section and flux information presented in Sect. 2 are used to estimate the portion of the observed ${ }^{14} \mathrm{C}$ level that was due to ${ }^{13} \mathrm{C}$.

As expected, observed ${ }^{14} \mathrm{C}$ levels in element E11-07 (the 701-EFPD element) fall below ${ }^{14} \mathrm{C}$ levels in the full-term elements, except for the E14-01 spine. The low levels observed in the spine of element E14-01 may be ascribed to the presence of boron in the hollowed-out portion of the spine contained in the lower two-thirds of the fuel element. The boron poison evidently depressed the flux in the central part of this fuel element, causing lower ${ }^{14} \mathrm{C}$ production in this zone. Reference 4 provides a full description of this poisoned fuel element, which was one of 60 such elements in the core.

In contrast to the flat distribution exhibited throughout the graphite interior, it appears reasonable to assume that the surface concentration peaks were caused by nitrogen deposited in short-term exposures during reactor operation. Their very narrow width, usually less than $0.5 \mathrm{~mm}$, strongly indicates this sort of a cause. In Sect. 4.2, an unsuccessful attempt is made to quantitatively relate these surface peaks to observed intermittent increases of $\mathrm{N}_{2}$ contaminant in the coolant, which resulted from various maintenance activities. 


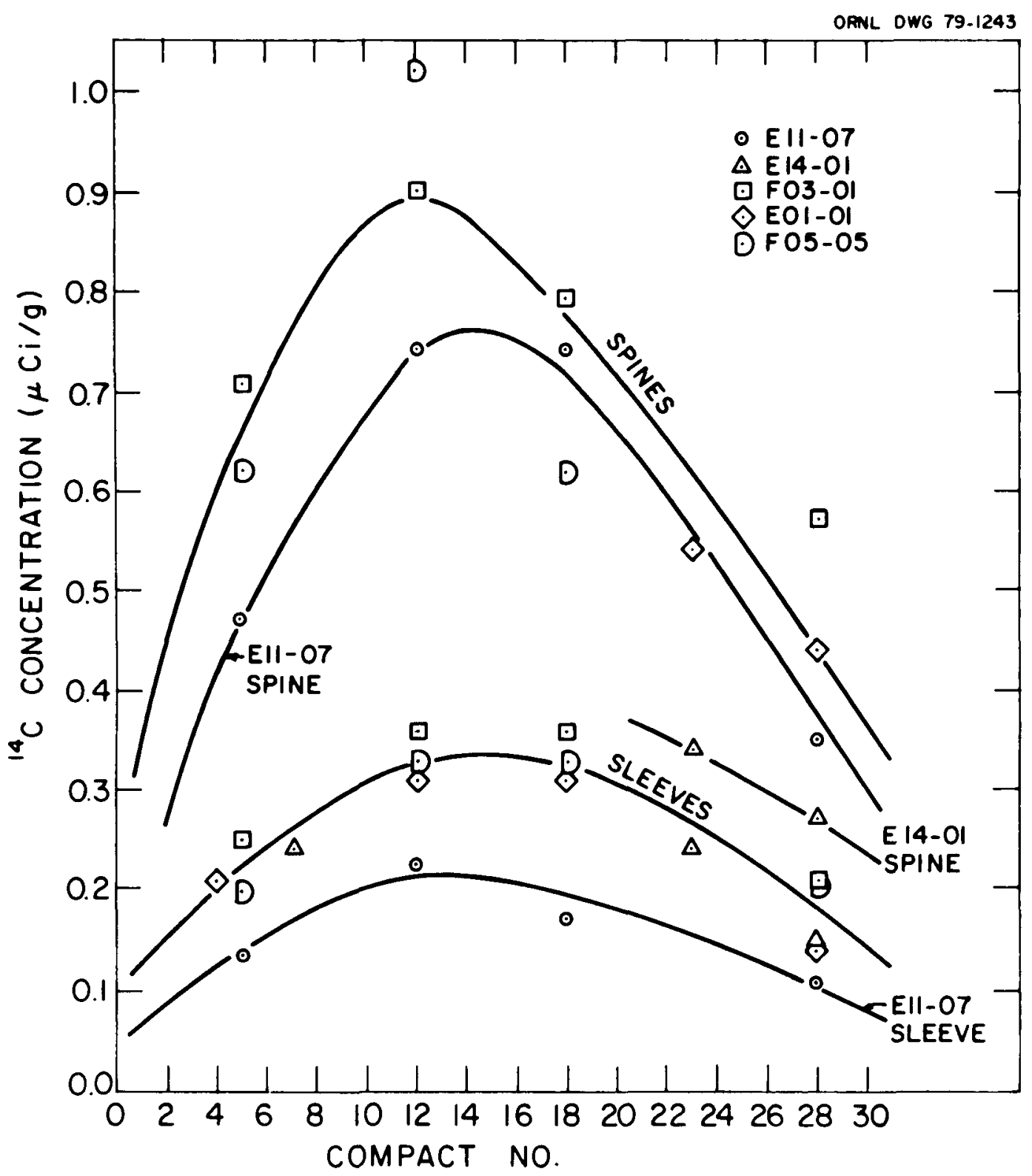

Fig. 3.3. Carbon-14 concentrations in the interior portions of the sleeves and spines. 


\subsection{Inventory in the Sleeves and Spines}

The inventory of ${ }^{14} \mathrm{C}$ contained in the sleeves and spines of the fuel elements may be determined by using the following two-step procedure:

(1) graphical integration of the axial distributions shown in Fig. 3.3, which yields the amount of ${ }^{14} \mathrm{C}$ associated with the interior graphite where the radial profile is flat, and (2) graphical integration of the radial profiles (Figs. A.1 to A.10), which may then be used to determine the amount of ${ }^{14} \mathrm{C}$ contained in the concentration peaks near each graphite surface relative to the flat, interior zone.

Graphical integration of the axial concentration distribution in the spines of elements F03-01, E01-01, and F05-05 (Fig. 3.1) determines the average ${ }^{14} \mathrm{C}$ concentration in the nonpoisoned, EOL spines to be $0.67 \mu \mathrm{Ci} / \mathrm{g}$. Because the total mass of spines in 711 fuel elements (804 element locations minus 33 fuel test elements and 60 poisoned elements) is estimated as $4.13 \times 10^{6} \mathrm{~g}$, the amount of ${ }^{14} \mathrm{C}$ contained in the spines of these elements is determined to be $2.8 \mathrm{Ci}$.

The partial axial profile curve for element E14-01 (Fig. 3.1) indicates that the average ${ }^{14} \mathrm{C}$ level in this poisoned spine is about 0.33 $\mu \mathrm{Ci} / \mathrm{g}$. Thus the poisoned spines of the 60 fuel elements like E14-01 contribute an estimated $0.1 \mathrm{C} i$ to the core inventory of ${ }^{14} \mathrm{C}$.

Similarly, the average ${ }^{14} \mathrm{C}$ concentration in the fuel element sleeves is determined to be $0.24 \mu \mathrm{Cl} / \mathrm{g}$, which yields, for a mass of $8.64 \times 10^{6} \mathrm{~g}$ for 804 fuel element sleeves, a total inventory of $2.1 \mathrm{Ci}$ contained in the interior portions of the graphite sleeves.

The above estimates relate exclusively to the portion of ${ }^{14} \mathrm{C}$ in sleeves and spines contained in the interior graphite, and exclude the amount observed in the concentration peaks near the graphite surfaces. Examination of these surface concentration peaks, shown in Tables A.1 through A.35, indicates that the largest ones occur near the outside diameter of the spine. Here, surface concentrations may be found which range up to about $5.8 \mu \mathrm{Ci} / \mathrm{g}$ above the interior level, although the depth of penetration is quite small - 0.2 to $0.6 \mathrm{~mm}$. Graphical integration of the concentration peaks found on the spine exterior surface indicates 
that they contain about $0.14 \mathrm{Ci}$ of ${ }^{14} \mathrm{C}$. This estimate is based on the average peak area above the level interior graphite concentration of all five fuel elements examined.

The amount of ${ }^{14} \mathrm{C}$ contained near sleeve inside surfaces and spine surfaces is less than that found on the outside of the sleeves. At the sleeve inside diameter, a peak concentration range of 0 to $1.0 \mathrm{\mu g} / \mathrm{g}$ was observed with depths ranging from 0 to $2 \mathrm{~mm}$. The total amount of ${ }^{14} \mathrm{C}$ estimated near the sleeve inside diameter is $0.15 \mathrm{Ci}$. Concentration peaks on the outer sleeve surface range from 0.6 to $2.3 \mu \mathrm{Ci} / \mathrm{g}$ with depths of 0.2 to $0.6 \mathrm{~mm}$. An estimated $0.31 \mathrm{Ci}$ of ${ }^{14} \mathrm{C}$ is contained in the concentration peaks observed near the outer sleeve surface.

The concentrations and inventory estimates of ${ }^{14} \mathrm{C}$ in the fuel element sleeves and spines are summarized in Table 3.2.

Table 3.2. Average concentrations and estimated amounts of ${ }^{14} \mathrm{C}$ in fuel element sleeves and spines

(Values are microcuries per gram.)

\begin{tabular}{lr}
\hline \multicolumn{2}{c}{ Average concentration } \\
Nonpoisoned, EOL spines & $0.67^{a}$ \\
Poisoned spines & $0.33^{a}$ \\
EOL sleeves & $0.24^{a}$
\end{tabular}

Estimated inventory

Spines

Interior graphite $\quad 2.9$

Surface peaks 0.14

Sleeves

Interior graphite $\quad 2.1$

Exterior surface $\quad 0.31$

Interior surface $\underline{0.15}$

Total 5.6

$a_{\text {Values }}$ refer to ${ }^{14} \mathrm{C}$ associated with the flat radial profile; contributions from the surface peaks are excluded. 
3.3 Inventory and Distribution in the Fuel Element Fission Product Traps

A surprisingly large amount of ${ }^{14} \mathrm{C}$ was found in the fission product traps contained within each fuel element.* In fact, these traps contained almost as much ${ }^{14} \mathrm{C}$ as did all the sleeves and spines, despite their location outside the active core and their comparatively small size (the mass of carbon in the traps was only $0.6 \%$ of that in the sleeves and spines combined).

The axial distributions of ${ }^{14} \mathrm{C}$ found in the fission product traps of four fuel elements are shown in Fig. 3.4. The upper curve is drawn through data obtained for three nonpoisoned, EOL elements - F03-01, E01-01, and F05-05. Note here that after the first $10.2 \mathrm{~cm}$ ( $4 \mathrm{in.)}$ of trap, the concentration declines in a manner expected in a nonsaturated adsorber bed. The cause of the decline appears to be due to a continuously diminishing adsorbate concentration in the gas as it passes through the bed.

Duplicate charcoal samples were acquired at each axial location for the traps in elements E01-01 and F05-05. The average range in measured ${ }^{14} \mathrm{C}$ activity within these sample pairs is $9 \%$. Therefore, an average error of $\pm 4.5 \%$, ascribable principally to sampling variations, may be associated with each of the data points shown for the EOL elements. Thus the qualitatively different trend in the F05-05 profile appears to be real; however, without significantly more data, it is not possible to determine a cause for the difference.

The average concentration in the traps of the three EOL fuel elements is approximately $67 \mu \mathrm{Ci} / \mathrm{g}$, based on the axial profile indicated in Fig. 3.4. No axial profile was obtained for the poisoned spine element E14-01. However, the charcoal in this trap was collected in four axial portions and was found ${ }^{4}$ to contain an average concentration of $54.6 \mu \mathrm{Ci} / \mathrm{g}$ of ${ }^{14} \mathrm{C}$. This is comparable to, though somewhat lower than, that found for the other EOL elements.

\footnotetext{
* Description and location of these traps are given in several of the examination reports (e.g., ref. 3, Fig. 2.1-6).
} 


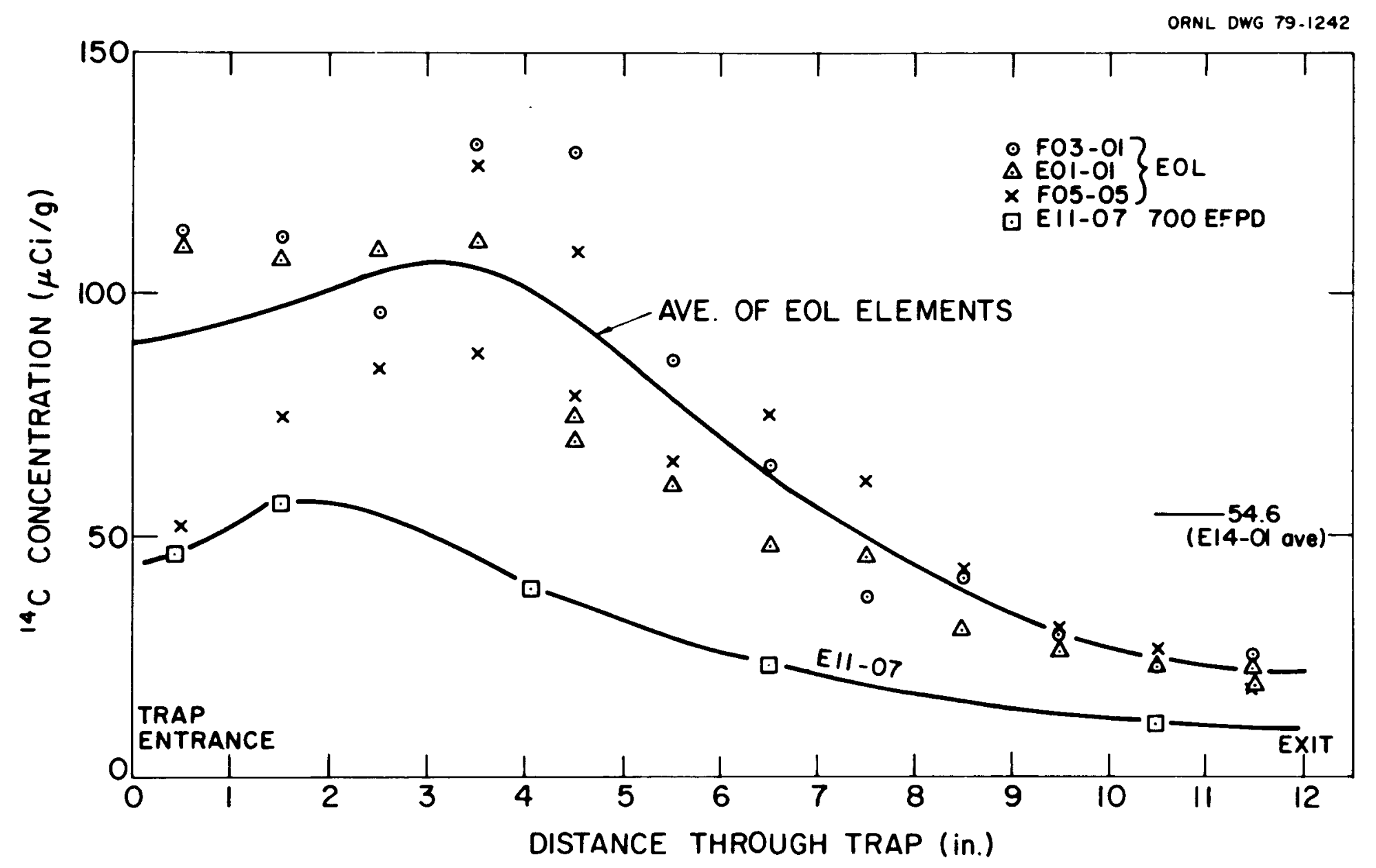

Fig. 3.4. Carbon-14 concentration profile in four fuel element fission product traps. 
Because each trap contained about $100 \mathrm{~g}$ of charcoal, $67 \mu \mathrm{Ci} / \mathrm{g}$ in 687 nonpoisoned elements (excluding fuel test elements) plus $55 \mu \mathrm{Ci} / \mathrm{g}$ in 84 poisoned elements amounts to about $5.1 \mathrm{Ci}$ of ${ }^{14} \mathrm{C}$ in the charcoal traps.

An interesting feature in Fig. 3.4 is the relatively low concentration of ${ }^{14} \mathrm{C}$ found in the trap of element E11-07, which was removed from the core after 701 EFPD, about 200 EFPD prior to EOL. The average trap concentration was less than one-half that observed for the EOL elements. A prorating based on irradiation time indicates that ${ }^{14} \mathrm{C}$ levels in the E11-07 trap should have been about $78 \%$ of the EOL traps.

The high ${ }^{14} \mathrm{C}$ levels found in the traps could be due either to high nitrogen impurity concentrations in the trap charcoal or to formation of ${ }^{14} \mathrm{C}$ in the active portion of the fuel element, followed by transport to the trap as a gaseous species in the fuel element purge flow. Estimates developed in Sect. 4.1 indicate that about 1 wt \% $\mathrm{N}_{2}$ in charcoal irradiated for the full term of core 2 at the average flux level in the core would yield the observed ${ }^{14} \mathrm{C}$ levels in the fission product traps.

(Although the traps were below the active core, they were in a zone where significant flux existed.)

\subsection{Inventory in the Fuel}

The limited number of measurements that were performed on the ${ }^{14} \mathrm{C}$ content of fuel particles during the Peach Bottom Surveillance Program are summarized in Table 3.3. These data refer to measured ${ }^{14} \mathrm{C}$ amounts found in a series of 12 particle pairs taken from compacts 2, 13, 20, and 24 of fuel element E11-07. Note that observed amounts of ${ }^{14} \mathrm{C}$ range from $5.63 \times 10^{-3}$ to $2.7 \times 10^{-4} \mu \mathrm{Ci}$ per particle pair. From these measurements, the average amount per fuel particle is $1.2 \times 10^{-3} \mu \mathrm{Ci}$.

Because past measurements show the cesium fission product to be immobile within the Peach Bottom fuel element, measuring concentrations relative to the radionuclide ${ }^{144} \mathrm{Ce}$ is a convenient way of assessing the movement of a species. The relatively constant values of the ${ }^{14} \mathrm{C} /{ }^{144} \mathrm{Ce}$ ratio shown in Table 3.3 for fuel compacts 13, 20, and 24 indicate that ${ }^{14} \mathrm{C}$ did not move significantly from these compacts. The lower ratios 
Table 3.3. Measured ${ }^{14} \mathrm{C}$ inventory in fuel particle pairs from element E11-07

(corrected to Sept. 14, 1973)

\begin{tabular}{|c|c|c|c|}
\hline $\begin{array}{c}\text { Compact } \\
\text { No. }\end{array}$ & $\begin{array}{l}\text { Fuel } \\
\text { particle } \\
\text { pair }\end{array}$ & $\begin{array}{l}\text { Measured }{ }^{14} \mathrm{C} \\
(\mu \mathrm{Ci} / \mathrm{samp} 1 \mathrm{e})\end{array}$ & $\begin{array}{c}{ }^{14} \mathrm{C} /{ }^{144} \mathrm{Ce} \\
\text { ratio }\end{array}$ \\
\hline 2 & $\begin{array}{ll}3, & 4 \\
5, & 6 \\
9, & 10\end{array}$ & $\begin{array}{l}2.9 \mathrm{E}-4^{a} \\
2.7 \mathrm{E}-4 \\
7.6 \mathrm{E}-4\end{array}$ & $\begin{array}{l}1.4 \mathrm{E}-6 \\
8.7 \mathrm{E}-7 \\
2.5 \mathrm{E}-6\end{array}$ \\
\hline 13 & $\begin{aligned} 7, & 8 \\
9, & 10 \\
11, & 12\end{aligned}$ & $\begin{array}{l}2.77 \mathrm{E}-3 \\
5.63 \mathrm{E}-3 \\
2.55 \mathrm{E}-3\end{array}$ & $\begin{array}{l}7.39 \mathrm{E}-6 \\
7.32 \mathrm{E}-6 \\
7.26 \mathrm{E}-6\end{array}$ \\
\hline 20 & $\begin{array}{ll}3, & 4 \\
5, & 6 \\
9, & 10\end{array}$ & $\begin{array}{l}3.04 \mathrm{E}-3 \\
2.11 \mathrm{E}-3 \\
1.65 \mathrm{E}-3\end{array}$ & $\begin{array}{l}8.23 E-6 \\
9.45 E-6 \\
6.39 E-6\end{array}$ \\
\hline 24 & $\begin{aligned} 7, & 8 \\
9, & 10 \\
11, & 12\end{aligned}$ & $\begin{array}{l}2.79 E-3 \\
2.79 E-3 \\
3.45 E-3\end{array}$ & $\begin{array}{l}5.72 E-6 \\
6.18 E-6 \\
5.67 E-6\end{array}$ \\
\hline
\end{tabular}

shown for compact 2 indicate that perhaps some movement occurred, although there are too few data for firm conclusions.

The average amount of uranium per fuel particle was determined to be $15.0 \mu \mathrm{g}$ based on measurements of 200 fuel particles taken from an archive compact. ${ }^{14}$ Because the total loading of uranium in core 2 was $189.6 \mathrm{~kg}$, the core contained approximately $1.26 \times 10^{10}$ fuel particles. Thus the ${ }^{14} \mathrm{C}$ inventory in the fuel is estimated to be $1.2 \times 10^{-3} \mu \mathrm{Ci}$ per particle times $1.26 \times 10^{10}$ particles, or $15.1 \mathrm{Ci}$, based on the E11-07 data. Because this element was removed before EOL, the core inventory at EOL is estimated by the ratio of EFPD at EOL to the value at time of removal (i.e., 897/701). This yields an estimated ${ }^{14} \mathrm{C}$ inventory of 19.4 $\mathrm{Ci}$ in the fuel particles at EOL. 
Because ${ }^{14} \mathrm{C}$ is not formed by fission and because the mass of carbon associated with fuel particles is small in comparison with the sleeve and spine $\left(1.3 \times 10^{6} \mathrm{~g}\right.$ vs $\left.12.7 \times 10^{6} \mathrm{~g}\right)$, the relatively large ${ }^{14} \mathrm{C}$ inventory in the fuel compared with that in all of the sleeve and spine graphite must be attributed to high oxygen and nitrogen contamination levels in the fuel. This was not confirmed by direct measurement but seems reasonable based on the fuel manufacturing and storage procedures that were used. Though records are sparse, discussions with personnel at General Atomic Company involved with Peach Bottom fuel manufacture indicate that the levitating gas for the kernel coating operation may have been nitrogen. (About a 50\% chance for this was stated.) In addition, the uncoated kernels were stored in inert boxes under nitrogen prior to coating, and the finished fuel particles were stored in air. Therefore, it seems entirely reasonable that the high ${ }^{14} \mathrm{C}$ levels observed in the fuel particles were due to nitrogen contamination.

\subsection{Inventory in the Removable Radial Reflector}

The active core of the reactor was surrounded by three radial rows (rows 18 to 20) of solid, hexagonal, graphite elements termed the removable radial reflector. Each of these elements weighed $40.5 \mathrm{~kg}$, so the total mass of 341 such elements was $1.38 \times 10^{4} \mathrm{~kg}$.

Reflector element A18-08 was sectioned and analyzed for ${ }^{14} \mathrm{C}$ concentration. Since this element was in the inner reflector row, two of its six faces were adjacent to the active fuel elements A17-07 and A17-08. These faces are indicated in Fig. 3.5 by an asterisk. The samples were prepared by cutting cross-sectional wafers of about 4-mm thicknesses at $30.5-\mathrm{cm}(1-\mathrm{ft})$ intervals along the element beginning $30.5 \mathrm{~cm}$ from the bottom of the core. The wafers are referred to by numbers 1 through 11 from bottom to top to identify their axial location. The radial distributions of tritium within the reflector were determined in the five wafers numbered $2,4,6,8$, and 11 .

The sampling locations and results are shown schematically in Fig. 3.4. The numbers within the hexagonal cross sections denote the 
ACTIVE CORE

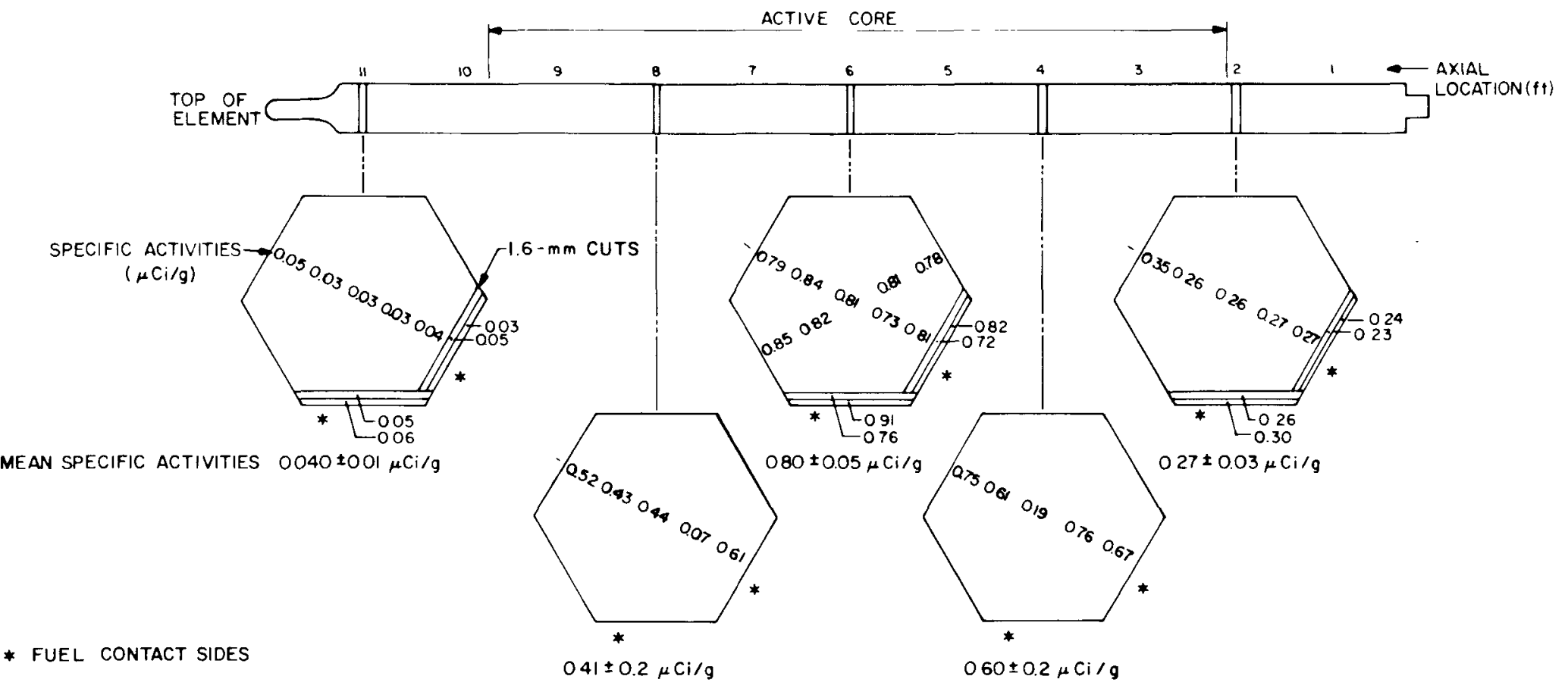

Fig. 3.5. Carbon-14 concentrations in removable reflector element. 
observed ${ }^{14} \mathrm{C}$ concentrations. These data appear on the figure at locations that roughly correspond to the sampling locations. Most of the sampling was done by drilling through the wafers and collecting the dust that was generated. The samples taken near the exterior were within about 6 to $8 \mathrm{~mm}$ of the edges. Generally, samples were acquired at five equally spaced locations across each wafer starting at an edge that had been adjacent to a fuel element. Note that an $X$-shaped sampling pattern was used on wafer 6 . In addition to specimens obtained by drilling, two samples were obtained from wafers 2,6 , and 11 by shaving off 2 to $3 \mathrm{~mm}$ of graphite from the edges adjacent to the fuel. These are precisely the same samples for which tritium concentrations were reported earlier. ${ }^{8}$

The measured concentrations show a clear flux dependence in the axial direction, with the maximum value of $0.80 \mu \mathrm{Ci} / \mathrm{g}$ shown for the samples taken from the wafer near midplane and the minimum average value of $0.040 \mu \mathrm{Ci} / \mathrm{g}$ observed for the wafer above the active core. The concentrations observed near midplane are comparable to those observed for the fuel element spines near midplane and are distinctly higher than found in the sleeves (Fig. 3.4). No clear lateral dependence is seen, however; the samples near the fuel contact side are not clearly higher in ${ }^{14} \mathrm{C}$ than those farther from the core. Also, surface samples do not exhibit concentration peaks as observed in the sleeve and spine material.

The axial average concentration in the removable radial reflector, determined by weighted average of the five cross section averages shown in Fig. 3.5, is estimated as $0.37 \mu \mathrm{Ci} / \mathrm{g}$. Applying this average value to all three rows of reflector elements indicates the ${ }^{14} \mathrm{C}$ content in the radial reflector to be $5.1 \mathrm{Ci}$. This estimate is probably high because the outer reflector rows most likely contained less ${ }^{14} \mathrm{C}$ than the examined element. Since the removable reflector blocks were not changed following the operation of core 1, only a part of this inventory may be ascribable to core 2 operation. Core 1 operated for 450 EFPD compared with 897 for core 2. Therefore, an estimated $67 \%(897 / 1347)$, or $3.4 \mathrm{Cl}$, of the observed reflector inventory was due to core 2 operation. 


\section{PREDICTED CONCENTRATIONS OF CARBON-14}

In this section an attempt is made to understand the reason for the unusual radial concentration profiles observed in the sleeve and spine graphite (Figs. 3.1 and 3.2). Toward this goal, an estimate will first be made of the expected ${ }^{14} \mathrm{C}$ concentration produced from the reaction ${ }^{13} \mathrm{C}(\mathrm{n}, \gamma){ }^{14} \mathrm{C}$. Because the $\mathrm{flux}$ and the level of the ${ }^{13} \mathrm{C}$ isotope impurity were both constant throughout the cross section at each axial location, the resulting ${ }^{14} \mathrm{C}$ level would also be radially flat. Therefore, such a calculation (outlined in Sect. 4.1) provides an estimate of the extent to which the radially uniform portion of concentration profile results from the ${ }^{13} \mathrm{C}$ isotope. In Sect. 4.2, an estimate is made of the oxygen and nitrogen contamination levels which would have resulted in a $1-\mu \mathrm{Ci} / \mathrm{g}$

concentration of ${ }^{14} \mathrm{C}$. The contamination levels thereby required to produce the observed surface concentration peaks are then compared with anticipated impurity levels either from exposure to air or exposure to the nitrogen impurity in the helium coolant.

\subsection{Production from ${ }^{13} \mathrm{C}$}

In Sects. 3.1 and 3.2, it was shown that about $90 \%$ of the ${ }^{14} \mathrm{C}$ observed in the fuel element sleeves and spines was spread uniformly across the width of the graphite with the balance concentrated in surface peaks. In this section, we will try to determine the portion of the radially uniform deposit attributable to the reaction ${ }^{13} \mathrm{C}(\mathrm{n}, \mathrm{y}){ }^{14} \mathrm{C}$. Since neither the cross section dependence on energy of this reaction nor the neutron spectrum is accurately known, only a rough calculation is warranted. First, an estimate is made of the flux in each of the six lowest energy groups averaged over the lifetime of core 2. Scoping calculations showed that a preponderant portion of the total production is contributed by these lowest neutron energy groups. Second, groupaveraged cross sections are estimated based on a presumed $1 / \mathrm{V}$ dependence in this energy range. Finally, production from ${ }^{13} \mathrm{C}$ is estimated by summing the contributions from each energy group. 
In Sect. 2.1 we noted that cross sections for the reactions ${ }^{14} \mathrm{~N}(\mathrm{n}, \mathrm{p}){ }^{14} \mathrm{C}$ and ${ }^{17} \mathrm{O}(\mathrm{n}, \alpha){ }^{14} \mathrm{C}$ were $1 / \mathrm{V}$ dependent up to about $10 \mathrm{keV}$, with resonances appearing above about $0.2 \mathrm{MeV}$. Although no similar information is available for the ${ }^{13} \mathrm{C}(n, \alpha){ }^{14} \mathrm{C}$ reaction, it is reasonable to assume analogous behavior for these three light nuclides.

Section 2.1 also summarized average flux levels for the four energy groups employed in Peach Bottom calculations, as well as a more refined, 15-group estimate of a neutron energy spectrum based on a large HTGR with approximately equal $\mathrm{C} / \mathrm{U}$ ratio. Scoping calculations showed that for this spectrum, reactions with light nuclides would occur predominantly in the thermal end of the spectrum, up to $13.7 \mathrm{eV}$ (i.e., in energy groups 10 to 15 shown in Table 2.3).

Table 4.1 lists estimated values of the average flux in these six flux groups. The flux levels were selected to conform to the spectrum illustrated in Fig. 2.2 and to add up to the estimated values of the corresponding four-group averages employed in Peach Bottom neutronics calculations given in Table 2.2. Hence these averages are based on the total operating time of 1068 days, which includes periods of low-power operation but excludes shutdown intervals. Linear extrapolations were used where groups overlap, such as for groups 11 and 9 . The low energy limit listed for group 15 is a rough estimate of the Maxwellian cutoff. For this purpose, an average core temperature of $530^{\circ} \mathrm{C}$ was assumed, which is the average of the inlet and outlet coolant temperatures; the thermal cutoff was assumed to occur at an energy level of $20 \%$ below the mean energy corresponding to $530^{\circ} \mathrm{C}$.

Table 4.2 lists the group cross sections for the three important reactions that produce ${ }^{14} \mathrm{C}$. These averages were based on the $0.025-\mathrm{eV}$ values given in Table 2.1 together with the assumptions of (1) $1 / \mathrm{V}$ dependence of the cross section, and (2) a flux variation of $1 / E$. Both assumptions are closely approximated in all except the lowest energy group.

The average ${ }^{14} \mathrm{C}$ concentration in the graphite sleeves and spines due to the reaction with ${ }^{13} \mathrm{C}$ was computed using 
Table 4.1. Average Peach Bottom fluxes during operation of core 2

in thermal and near-thermal range

\begin{tabular}{|c|c|c|c|c|c|c|}
\hline \multicolumn{4}{|c|}{ Fifteen-group fluxes } & \multicolumn{3}{|c|}{ Peach Bottom four-group fluxes } \\
\hline Group & Ener & $\begin{array}{l}\text { range } \\
\text { V) }\end{array}$ & $\begin{array}{l}\text { Flux } \\
\left(1 / \mathrm{cm}^{2} \cdot s\right)\end{array}$ & Group & $\begin{array}{c}\text { Energy range } \\
(\mathrm{eV})\end{array}$ & $\begin{array}{c}\text { Flux } \\
\left(1 / \mathrm{cm}^{2} \cdot \mathrm{s}\right)\end{array}$ \\
\hline 15 & 0.0554 & 0.0823 & $5.94 \mathrm{E} 12^{a}$ & & & \\
\hline 14 & 0.0823 & 0.249 & $1.73 \mathrm{E} 13$ & & & \\
\hline 13 & 0.249 & 0.881 & $1.23 \mathrm{E} 13$ & Therma1 & $0-2.38$ & 4. $09 \mathrm{E} 13$ \\
\hline 12 & 0.881 & 1.86 & $4.08 \mathrm{E} 12$ & & & \\
\hline 11 & 1.86 & 5.04 & $5.00 \mathrm{E} 12$ & $\downarrow$ & $\downarrow$ & $\downarrow$ \\
\hline 10 & 5.04 & 13.7 & $5.27 \mathrm{E} 12$ & 3 & $2.38-17.6$ & $\begin{array}{c}1.04 \mathrm{E} 13 \\
\mathrm{I}\end{array}$ \\
\hline 9 & 13.7 & 47.9 & & $\frac{1}{\gamma}$ & v & $\gamma$ \\
\hline
\end{tabular}

$a_{\text {Read as }} 5.94 \times 10^{12}$. 
Table 4.2. Group cross sections for ${ }^{14} \mathrm{C}$-producing reactions

\begin{tabular}{llllllll}
\hline Reaction & Units & $\bar{\sigma}_{15}$ & $\bar{\sigma}_{14}$ & $\bar{\sigma}_{13}$ & $\bar{\sigma}_{12}$ & $\bar{\sigma}_{11}$ & $\bar{\sigma}_{10}$ \\
\hline${ }^{13} \mathrm{C}(\mathrm{n}, \gamma)$ & $\mathrm{mb}$ & 0.545 & 0.362 & 0.198 & 0.124 & 0.0786 & 0.0479 \\
${ }^{14} \mathrm{~N}(\mathrm{n}, \mathrm{p})$ & $\mathrm{b}$ & 1.10 & 0.729 & 0.398 & 0.249 & 0.159 & 0.0966 \\
${ }^{17}(\mathrm{n}, \alpha)$ & $\mathrm{b}$ & 0.124 & 0.0949 & 0.0517 & 0.0323 & 0.0206 & 0.0125 \\
\hline
\end{tabular}




$$
N_{14}(t)=N_{13}^{0}\left[1-\exp \left(-t \sum \phi_{i} \sigma_{i}\right)\right]
$$

and

$$
\frac{\mu C i}{g}=N_{14} \frac{\lambda}{3.7 \times 10^{4}}
$$

The summation was taken from group 15 through group 10, which accounts for about $98 \%$ of the production. The initial concentration of ${ }^{13} \mathrm{C}, \mathrm{N}_{13}^{0}$, was calculated from an isotopic abundance of $1.1 \%$ and a graphite density of $1.8 \mathrm{~g} / \mathrm{cm}^{3}$. Using a core lifetime, $t$, of 1068 days and a decay constant of $3.89 \times 10^{-12} \mathrm{~s}^{-1}$ for ${ }^{14} \mathrm{C}$ yields $0.071 \mu \mathrm{Ci} / \mathrm{g}$ of ${ }^{14} \mathrm{C}$ from ${ }^{13} \mathrm{C}$ according to the above information.

It may be readily shown that ${ }^{14} \mathrm{C}$ production from adsorbed oxygen in the graphite is negligible compared with that due to nitrogen, despite the possibility that oxygen contaminant levels may be several times higher. The reasons for this are a lower reaction cross section by about a factor of 10 and a low isotopic abundance $(0.039 \%)$ of ${ }^{17} 0$.

An average concentration of $0.24 \mu \mathrm{Ci} / \mathrm{g}$ was observed in the interior portions of EOL sleeves (Table 3.2). About $30 \%$ of this amount $(0.071 /$ $0.24)$ may therefore be attributed to ${ }^{13} \mathrm{C}$. Similarly, about $11 \%(0.071$ of $0.66 \mu \mathrm{Ci} / \mathrm{g}$ ) of the observed average ${ }^{14} \mathrm{C}$ level in nonpoisoned, EOL spines could be due to ${ }^{13} \mathrm{C}$.

The higher observed levels in the interior of the spines relative to the sleeves can by elimination only be ascribed to higher levels of adsorbed air in the spines at the time of core start-up. No other explanation seems possible because flux levels in the sleeves and spines must have been nearly equal, and no difference in ${ }^{13} \mathrm{C}$ concentration is plausible. There would be ample time for adsorption of air between graphite manufacture, at which time all oxygen and nitrogen would be driven off by graphitization temperatures of at least $2800^{\circ} \mathrm{C}$, and the time of installing core 2. Preoperational testing would release some of the adsorbed oxygen as $\mathrm{CO}$ and $\mathrm{CO}_{2}$, but the major portion would remain up to temperatures of about $1300^{\circ} \mathrm{C}$. In addition, nitrogen does not desorb until graphite is heated to about $1300^{\circ} \mathrm{C} .{ }^{15}$ Therefore, most of the air adsorbed on graphite during preoperational handling would still be there 
at the time of core start-up. However, no explanation is offered for the reason such purported air contamination levels would be higher in the spine graphite than in that of the sleeve.

\subsection{Surface Concentration Peaks in the Sleeves and Spines}

The radial profiles shown in Figs. 3.1 and 3.2 illustrate the general feature of the observed concentration distribution across the sleeves and spines. The major fraction of the ${ }^{14} \mathrm{C}$ was found in the radially flat portions of the profile, but about $5 \%$ of the ${ }^{14} \mathrm{C}$ in the spines and $22 \%$ in the sleeves were associated with surface concentration peaks. In the previous section, it was shown that from 10 to $30 \%$ of the ${ }^{14} \mathrm{C}$ found in the interior graphite could be due to an $(n, \gamma)$ reaction with ${ }^{13} \mathrm{C}$, with the balance resulting from other neutron reactions with a radially uniform deposit of nitrogen and oxygen. It was postulated that such uniform adsorption of these gases would be due to an extended exposure to air after the time of graphite manufacture, during component fabrication, reaction installation, and up to reactor start-up.

Following start-up, the graphite surfaces in the core were exposed to generally low concentrations of nitrogen and oxygen in the helium coolant during periods of steady operation. Occasionally, however, concentrations of these gases rose either during a start-up transient or as a result of various maintenance procedures. The observed normal opera-

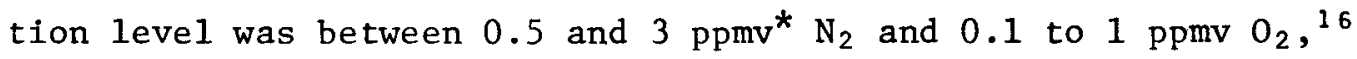
determined by continuous monitoring of the coolant with a gas chromatograph. Nitrogen concentration peaks of about 10 ppmv occurred frequently during reactor operation. However, by far the largest concentrations of nitrogen in the coolant occurred during the maintenance/refueling periods, which began in September 1973 and extended through December, and during the maintenance shutdown in mid-1974 just a few months before final shutdown. On both these occasions, the nitrogen concentration rose to about 1100 ppmv and remained at that level for about 4 months, in the first case, and 1 month in the latter instance.

\footnotetext{
${ }^{*}$ Parts per million by volume.
} 
Because no sorption data exist for nitrogen or oxygen on graphite at these temperatures, it is not possible to directly relate the exposures of these gases to graphite which occurred during maintenance and refueling operations to the observed surface concentrations of ${ }^{14} \mathrm{C}$. However, some idea of the adsorbed nitrogen levels involved may be seen from outgassing data for another graphite. ${ }^{15}$ It was found that a sample of Speer graphite contained about $20 \mathrm{ppm} \mathrm{N}_{2}$ after normal air exposure, as measured by gas evolution upon heating the sample to progressively higher temperatures. The nitrogen completely desorbed by about $1300^{\circ} \mathrm{C}$, which indicates that nitrogen tends to chemisorb rather strongly on graphite. The Speer graphite sample was found to contain a far higher amount of $\mathrm{O}_{2}$, about 160 $\mathrm{ppm}$, which was attributed not only to direct adsorption of oxygen, but also to reaction of atmospheric moisture with carbide impurities in the graphite forming a variety of oxygen-carbon compounds. Unlike nitrogen, oxygen degassing did not occur primarily at one temperature, but rather it was found that $\mathrm{CO}, \mathrm{CO}_{2}$, and $\mathrm{H}_{2} \mathrm{O}$ outgassed in the temperature range 600 to $1750^{\circ} \mathrm{C}$. However, as indicated earlier, ${ }^{14} \mathrm{C}$ production from adsorbed oxygen would be negligible in comparison to production from adsorbed nitrogen.

Because only about $0.25 \%$ of the nitrogen was converted to ${ }^{14} \mathrm{C}$ during the entire irradiation in core 2 , one can calculate the amounts of nitrogen required to generate the observed levels of ${ }^{14} \mathrm{C}$. Thus, about $93 \mathrm{ppm} \mathrm{N}_{2}$ would be required to produce $1 \mu \mathrm{Ci} / \mathrm{g}$ of ${ }^{14} \mathrm{C}$ at EOL. The concentration peaks observed on Peach Bottom fuel element surfaces ranged from 0.7 to $2.3 \mu \mathrm{Ci} / \mathrm{g}$ for the sleeve exteriors, up to $1.0 \mu \mathrm{Ci} / \mathrm{g}$ for the sleeve interiors, and from about 0.1 to $5.8 \mu \mathrm{Ci} / \mathrm{g}$ for the spine surfaces (Appendix, Figs. A.1 to A.11). Thus, an adsorbed concentration of about $540 \mathrm{ppm} \mathrm{N}_{2}$ would have had to be present on the surface of the spine for the entire span of core 2 operation to achieve a surface concentration of $5.8 \mu \mathrm{Ci} / \mathrm{g}$.

The highest reported nitrogen impurity level in the coolant, 1130 ppmv, which occurred late in the life of core 2, corresponds to only $0.03 \mathrm{~atm}$ at the total loop pressure of $30 \mathrm{~atm}$. Because air exposure (at 0.8 atm $\mathrm{N}_{2}$ ) resulted in only about $20 \mathrm{ppm} \mathrm{N}_{2}$ in a sample of Speer graphite, it appears unlikely that periodic exposure of the core internals 
to far lower nitrogen partial pressures could have caused the observed surface peaks of ${ }^{14} \mathrm{C}$. Although this appeared to be a reasonable hypothesis, the resulting ${ }^{14} \mathrm{C}$ concentrations would be substantially lower than the $5-\mu \mathrm{Ci} / \mathrm{g}$ concentrations observed on some spines.

This negative conclusion leaves the cause of the surface concentration peaks open for speculation. Most probably, some nitrogen-containing material was deposited on the sleeve and spine surfaces during either component manufacture or in-reactor service. Such deposit would have to have resulted in surface contamination levels of nitrogen far in excess of that achievable by adsorption from air or from the primary coolant. Some possibilities are (1) the impregnant employed in the final stages of graphite manufacture, (2) oil contamination from machining tools used in fabrication, or (3) oil deposits resulting from in-leakages from the circulator bearing lubrication system during reactor operation.

\section{SUMMARY AND CONCLUSIONS}

1. Carbon-14 concentrations in the graphite sleeves and spines of five fuel elements were measured in the course of the Peach Bottom Surveillance Program. Radial concentration profiles were obtained at four axial locations for each element; these data are provided in Tables A.1 through A.35 and plotted in Figs. A.1 through A.10.

2. Characteristically, the ${ }^{14} \mathrm{C}$ concentration was found to be constant at each axial location throughout most of the cross section. However, surface concentration peaks of less than 1-mm depth were found at al1 locations, containing about $5 \%$ of the spine and $22 \%$ of the sleeve inventory of ${ }^{14} \mathrm{C}$. These surface concentrations ranged from 0.7 to 2.3 $\mu \mathrm{Ci} / \mathrm{g}$ for the sleeve exterior, up to $1.0 \mu \mathrm{Ci} / \mathrm{g}$ for the interior sleeve surface, and from 0.1 to $5.8 \mu \mathrm{Ci} / \mathrm{g}$ for the spine surface.

3. In view of this characteristic radial profile, it is reasonable to assume that ${ }^{14} \mathrm{C}$ in the radially flat part of the profile was due to a combination of an $(n, \gamma)$ reaction with ${ }^{13} \mathrm{C}$ and to an $(n, p)$ reaction with ${ }^{14} \mathrm{~N}$ uniformly adsorbed throughout the graphite. This sort of a uniform 
deposit may be expected from extended contact of graphite with air, as occurred between the time of graphite manufacture and installation in the reactor core.

4. It was estimated that about $30 \%$ of the sleeve and $11 \%$ of the spine inventory of ${ }^{14} \mathrm{C}$ away from the surface peaks was due to the reaction ${ }^{13} \mathrm{C}(\mathrm{n}, \gamma){ }^{14} \mathrm{C}$, with the balance due to ${ }^{14} \mathrm{~N}(\mathrm{n}, \mathrm{p}){ }^{14} \mathrm{C}$. This estimate is highly uncertain in view of the unsure cross section for the reaction with ${ }^{13} \mathrm{C}$ beyond the thermal zone. The $(n, \alpha)$ reaction with ${ }^{17} 0$ was found to contribute negligibly to the ${ }^{14} \mathrm{C}$ inventory compared with the $(n, p)$ reaction with ${ }^{14} \mathrm{~N}$.

5. The surface concentration peaks observed on the sleeves and spines appear to have been caused by some material adsorbed on the surface during component manufacture or reactor operation. Even though the nitrogen level in the coolant frequently peaked as a result of various maintenance procedures, it is doubtful that these were the sole cause of the observed surface peaks because (1) the largest surface peaks were found on the spines instead of the more exposed sleeves, and (2) the peaks appear to be too large to result from nitrogen adsorption at the impurity levels that occurred in the coolant.

6. A surprisingly large amount of ${ }^{14} \mathrm{C}$ was found in the fuel element fission product traps. The average concentration found in the charcoal of the nonpoisoned, EOL elements was $67 \mu \mathrm{Ci} / \mathrm{g}$, corresponding to a total inventory in all the fuel element traps of $5.1 \mu \mathrm{Ci}$, which is only slightly less than that estimated for all the sleeve and spine graphite. Either the trap charcoal contained an unusually high level of nitrogen (about $1 \% \mathrm{~N}_{2}$ in charcoal on a mass basis would yield $67 \mu \mathrm{Ci} / \mathrm{g}{ }^{14} \mathrm{C}$, assuming a flux equal to the core average) or ${ }^{14} \mathrm{C}$ was contained in a gaseous compound which was carried to the charcoal trap by the fuel element purge flow.

7. Carbon-14 concentrations measured in a removable radial reflector element ranged from an average of $0.80 \mu \mathrm{Ci} / \mathrm{g}$ at midplane to an average of $0.040 \mu \mathrm{Ci} / \mathrm{g}$ at an axial location $40 \mathrm{~cm}$ above the active core. If the examined element was typical of the three rows of removable reflector elements, about $3.7 \mathrm{Ci}$ of ${ }^{14} \mathrm{C}$ would be contained therein. 
8. A series of 12 pairs of fuel particles taken from compacts 2 , 13, 20, and 24 of fuel element E11-07 were analyzed for ${ }^{14} \mathrm{C}$. The observed inventory levels ranged from $5.6 \times 10^{-3}$ to $2.7 \times 10^{-4} \mu \mathrm{Ci}$ per particle pair with an average value of $1.2 \times 10^{-3} \mu \mathrm{Ci}$ per particle. This corresponds to an estimated core-wide inventory of $19.4 \mathrm{Ci}$ associated with fuel particles.

9. Table 5.1 summarizes the observed levels of ${ }^{14} \mathrm{C}$ found in the examined core components. A total of $32.1 \mathrm{Ci}$ of ${ }^{14} \mathrm{C}$ is estimated to have been contained in the core as a result of core 2 operation. On a per unit energy basis, this amounts to a production rate of $113 \mathrm{Ci} / \mathrm{GW}(\mathrm{t})-$ yr.

Table 5.1. Summary of estimated ${ }^{14} \mathrm{C}$ inventories

based on observed concentrations

(Values are in curies.)

Fuel particles

19.4

Fuel element spines

Interior graphite

2.9

Surface peaks

0.14

Fuel element sleeves

Interior graphite

2.1

Exterior surface

0.31

Interior surface

0.15

Fission product traps in fuel elements 5.1

Removable radial reflector ${ }^{a}$

$\operatorname{Tota1}^{b} \quad \frac{3.4}{33.5}$

ascribable to core 2 operation.

$b_{\text {For components measured. }}$ 
10. Table 5.2 shows a comparison betwen the measured ${ }^{14} \mathrm{C}$ production rate in Peach Bottom per gigawatt (thermal)-year and predictions made by Davis. ${ }^{9}$ Considering all the uncertainties involved in the prediction, the comparison is quite good. The largest difference is between the measured and predicted production in fuel particles. Evidently, the Peach Bottom fuel contained significantly more nitrogen contamination than assumed in Davis' estimates.

Table 5.2. Carbon-14 production rate in Peach Bottom compared with predictions of Davis

[Values are $\mathrm{Ci} / \mathrm{GW}(\mathrm{t})-\mathrm{yr}$.

\begin{tabular}{|c|c|c|}
\hline & $\begin{array}{l}\text { Predicted by } \\
\text { Davis } a, b\end{array}$ & $\begin{array}{l}\text { Measured in } \\
\text { Peach Bottom }\end{array}$ \\
\hline Fue1 particles & 4.7 & 66.8 \\
\hline Core graphite & 65.6 & $37.8^{c}$ \\
\hline \multirow[t]{2}{*}{ Reflector graphite } & $\leq 10.6$ & $8.8^{d}$ \\
\hline & 80.9 & 113.4 \\
\hline \multicolumn{3}{|c|}{ 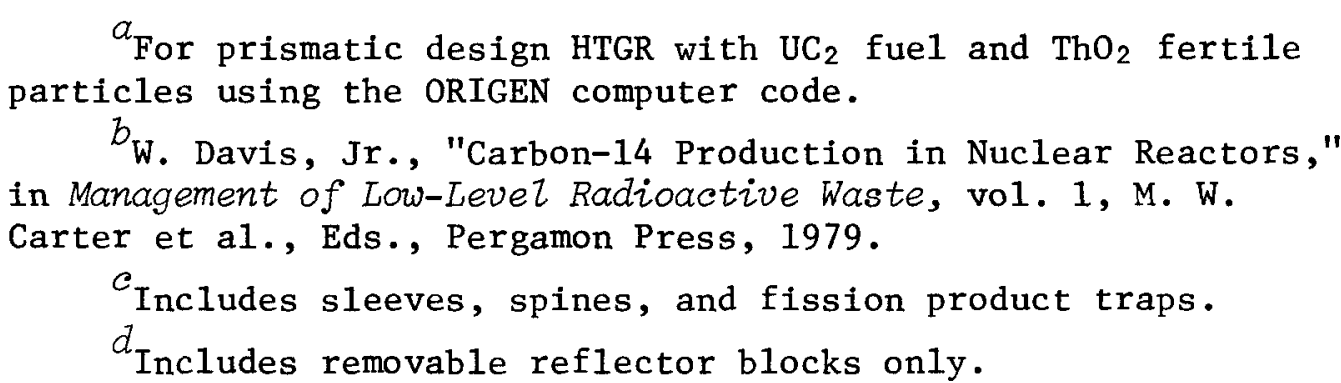 } \\
\hline
\end{tabular}

\section{REFERENCES}

1. F. F. Dyer et al., Distribution of Radionuclides in the Peach Bottom HTGR Primary Coolant During Core 2 Operation, ORNL-5188 (Apri1 1977).

2. F. F. Dyer et a1., Postirradiation Examination of Peach Bottom HTGR Driver Fuel Element E06-01, ORNL-5126 (March 1976). 
3. R. P. Wichner et a1., Distribution of Fission Products in Peach Bottom HTGR Fuel Element E11-07, ORNL-5214 (April 1977).

4. R. P. Wichner, F. F. Dyer, and W. J. Martin, Distribution of Fission Products in Peach Bottom HTGR Fuel Element E14-01, ORNL/TM-5730 (August 1977).

5. F. F. Dyer et a1., Distribution of Fission Products in Peach Bottom HTGR Fuel Element FO3-01, ORNL/TM-5996 (June 1978).

6. R. P. Wichner et a1., Distribution of Fission Products in Peach Bottom HTGR Fuel Element E01-01, ORNL/TM-6353 (August 1978).

7. R. P. Wichner et a1., Distribution of Fission Products in Peach Bottom HTGR Fuel Element F05-05, ORNL/TM-6455 (January 1979).

8. R. P. Wichner and F. F. Dyer, Distribution and Transport of Tritium in the Peach Bottom HTGR, ORNL-5497 (August 1979).

9. W. Davis, Jr., "Carbon-14 Production in Nuclear Reactors," in Management of Low-Level Radioactive Waste, vol. 1, M. W. Carter et a1., Eds., Pergamon Press, 1979.

10. S. F. Maghabghab and D. I. Garber, Neutron Cross Sections Vol. 1, Resonance Parameters, 3d ed., BNL 325 (June 1973).

11. Letters, F. McCord to C. F. Wallroth (internal correspondences, Genera1 Atomic Company), "Irradiation Summary of Element E06-01, June 27, 1975; "Irradiation Summary of Element E14-01," Aug. 14, 1975; and "Irradiation Summary of Element E11-07," June 25, 1975.

12. C. F. Wallroth et al., Postirradiation Examination and Evaluation of Peach Bottom Molded Fuel Test Element FTE-18, GA-A13699 (June 1976).

13. W. E. Thomas, Engineering Technology Division, ORNL, persona1 communication, 1978 .

14. R. P. Wichner and J. L. Botts, "Fuel Particle Failure Fractions in Peach Bottom HTGR Fuel Elements," Trans. Am. Nucl. Soc. 28, 689-91 (1978). 
15. W. P. Eatherly, private communication, June 1979.

16. W. J. Sheffel, N. L. Baldwin, and R. W. Tomlin, Operating History for the Peach Bottom HTGR, GA-A13907 (1976). 
- 
Appendix

MEASURED RADIAL CONCENTRATION DISTRIBUTIONS OF ${ }^{14} \mathrm{C}$ IN FUEL ELEMENT SLEEVES AND SPINES 
-

. 
Appendix. MEASURED RADIAL CONCENTRATION DISTRIBUTIONS OF ${ }^{14} \mathrm{C}$ IN FUEL ELEMENT SLEEVES AND SPINES

Tables A.1 through A.35 1ist measured concentrations of ${ }^{14} \mathrm{C}$ in graphite sleeves and spines of fuel elements E11-07, E14-01, F03-01, E01-01, and F05-05. For the fuel elements with no thermocouple groove in the spine (E11-07, F03-01, and F05-05), data are presented at axial locations approximately at compact numbers $5,12,18$, and 28 for both sleeves and spines. Fewer axial locations were measured for the other two fuel elements. These data were taken from postirradiation examinations performed for the Peach Bottom Surveillance Program (see refs.6, 7, 9-11, Sect. 6).

The tabulated radial distributions are plotted in Figs. A.1 through A. 10 .

Table A.1. Radial distribution of ${ }^{14} \mathrm{C}$ in E11-07 sleeve at compact 5

\begin{tabular}{ccc}
\hline $\begin{array}{c}\text { Thickness of sample } \\
(\mathrm{cm})\end{array}$ & $\begin{array}{c}\text { Radius } \\
(\mathrm{cm})\end{array}$ & $\begin{array}{c}{ }^{14} \mathrm{C} \\
\text { concentration } \\
(\mu \mathrm{Ci} / \mathrm{g})\end{array}$ \\
\hline 0.0127 & 0.0064 & 0.147 \\
0.0127 & 0.0191 & 0.140 \\
0.0127 & 0.0318 & 0.126 \\
0.0254 & 0.0509 & 0.134 \\
0.0762 & 0.140 & 0.114 \\
0.0762 & 0.292 & 0.135 \\
0.0762 & 0.446 & 0.112 \\
0.0762 & 0.597 & 0.131 \\
0.0762 & 0.749 & 0.136 \\
0.0381 & 0.883 & 0.156 \\
0.0203 & 0.950 & 0.721 \\
\hline
\end{tabular}

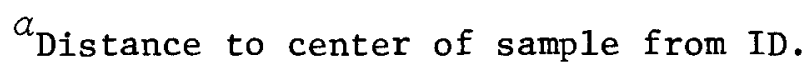


Table A.2. Radial distribution of ${ }^{14} \mathrm{C}$ in E11-07 sleeve at compact 12

\begin{tabular}{|c|c|c|}
\hline $\begin{array}{l}\text { Thickness of sample } \\
(\mathrm{cm})\end{array}$ & $\begin{array}{l}\text { Radius } \\
(\mathrm{cm})\end{array}$ & $\begin{array}{c}{ }^{14} \mathrm{C} \text { concentration } \\
(\mu \mathrm{Ci} / \mathrm{g})\end{array}$ \\
\hline 0.0127 & 0.0064 & 0.400 \\
\hline 0.0127 & 0.019 & 0.262 \\
\hline 0.0254 & 0.051 & 0.200 \\
\hline 0.0762 & 0.153 & 0.262 \\
\hline 0.0457 & 0.290 & 0.319 \\
\hline 0.0762 & 0.427 & 0.152 \\
\hline 0.0762 & 0.579 & 0.186 \\
\hline 0.0762 & 0.732 & 0.218 \\
\hline 0.0381 & 0.865 & 0.230 \\
\hline 0.0127 & 0.930 & 1.40 \\
\hline
\end{tabular}

Distance to center of sample from ID.

Table A.3. Radial distribution of ${ }^{14} \mathrm{C}$ in E11-07 sleeve at compact 18

\begin{tabular}{clc}
\hline $\begin{array}{c}\text { Thickness of sample } \\
(\mathrm{cm})\end{array}$ & $\begin{array}{c}\text { Radius }^{a} \\
(\mathrm{~cm})\end{array}$ & $\begin{array}{c}{ }^{14} \mathrm{C} \begin{array}{c}\text { concentration } \\
(\mu \mathrm{Ci} / \mathrm{g})\end{array} \\
0.0127\end{array}$ \\
0.0127 & 0.0064 & 0.799 \\
0.0127 & 0.019 & 0.718 \\
0.0127 & 0.032 & 0.391 \\
0.0762 & 0.045 & 0.197 \\
0.0762 & 0.127 & 0.235 \\
0.0762 & 0.279 & 0.174 \\
0.0762 & 0.432 & 0.193 \\
0.0762 & 0.584 & 0.194 \\
0.0381 & 0.737 & 0.180 \\
0.0229 & 0.870 & 0.193 \\
\hline
\end{tabular}

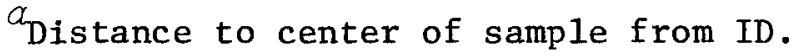


Table A.4. Radial distribution of ${ }^{14} \mathrm{C}$ in E11-07 sleeve at compact 28

\begin{tabular}{|c|c|c|}
\hline $\begin{array}{l}\text { Thickness of sample } \\
(\mathrm{cm})\end{array}$ & $\begin{array}{l}\text { Radius } \\
(\mathrm{cm})\end{array}$ & $\begin{array}{c}{ }^{14} \mathrm{C} \text { concentration } \\
(\mu \mathrm{Ci} / \mathrm{g})\end{array}$ \\
\hline 0.0127 & 0.0191 & 0.172 \\
\hline 0.0127 & 0.0318 & 0.179 \\
\hline 0.0127 & 0.0445 & 0.146 \\
\hline 0.0381 & 0.0699 & 0.132 \\
\hline 0.0762 & 0.127 & 0.107 \\
\hline 0.0762 & 0.279 & 0.109 \\
\hline 0.0762 & 0.432 & 0.107 \\
\hline 0.0762 & 0.584 & 0.107 \\
\hline 0.0762 & 0.737 & 0.111 \\
\hline 0.0381 & 0.870 & 0.116 \\
\hline 0.0254 & 0.940 & 0.566 \\
\hline
\end{tabular}

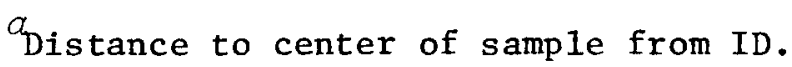

Table A.5. Radial distribution of ${ }^{14} \mathrm{C}$ in E11-07 spine at compact 5

\begin{tabular}{clc}
\hline $\begin{array}{c}\text { Thickness of sample } \\
(\mathrm{cm})\end{array}$ & $\begin{array}{c}\text { Radius } \\
(\mathrm{cm})\end{array}$ & $\begin{array}{c}{ }^{14} \mathrm{C} \text { concentration } \\
(\mu \mathrm{Ci} / \mathrm{g})\end{array}$ \\
\hline 0.0127 & 0.0064 & 0.561 \\
0.0381 & 0.0318 & 0.537 \\
0.0381 & 0.0699 & 0.473 \\
0.0762 & 0.127 & 0.487 \\
0.0762 & 0.203 & 0.423 \\
0.0762 & 0.356 & 0.413 \\
0.0762 & 0.508 & 0.526 \\
0.0762 & 0.660 & 0.467 \\
0.152 & 0.927 & 0.512 \\
0.159 & 1.72 & 0.535 \\
0.318 & 1.96 & 0.488 \\
\hline
\end{tabular}

Distance to center of sample from OD. 
Table A.6. Radial distribution of ${ }^{14} \mathrm{C}$ in E11-07 spine at compact 12

\begin{tabular}{|c|c|c|}
\hline $\begin{array}{l}\text { Thickness of sample } \\
\qquad(\mathrm{cm})\end{array}$ & $\begin{array}{l}\text { Radius } \\
(\mathrm{cm})\end{array}$ & $\begin{array}{c}{ }^{14} \mathrm{C} \text { concentration } \\
(\mu \mathrm{Ci} / \mathrm{g})\end{array}$ \\
\hline 0.0203 & 0.010 & 1.12 \\
\hline 0.0381 & 0.0394 & 0.75 \\
\hline 0.0381 & 0.0774 & 0.75 \\
\hline 0.0762 & 0.135 & 0.82 \\
\hline 0.0762 & 0.211 & 0.70 \\
\hline 0.0762 & 0.363 & 0.68 \\
\hline 0.0762 & 0.516 & 0.75 \\
\hline 0.0762 & 0.668 & 0.72 \\
\hline 0.1524 & 0.935 & 0.78 \\
\hline 0.159 & 1.699 & 0.72 \\
\hline 0.318 & 1.94 & 0.79 \\
\hline
\end{tabular}

$a_{\text {Distance to center of sample from } O D .}$

Table A.7. Radial distribution of ${ }^{14} \mathrm{C}$ in E11-07 spine at compact 18

\begin{tabular}{clc}
\hline $\begin{array}{c}\text { Thickness of sample } \\
(\mathrm{cm})\end{array}$ & $\begin{array}{c}\text { Radius } \\
(\mathrm{cm})\end{array}$ & $\begin{array}{c}{ }^{14} \mathrm{C} \text { concentration } \\
(\mu \mathrm{Ci} / \mathrm{g})\end{array}$ \\
\hline 0.0254 & 0.0127 & 1.29 \\
0.0381 & 0.0445 & 0.758 \\
0.0381 & 0.0826 & 0.722 \\
0.0762 & 0.140 & 0.735 \\
0.0762 & 0.216 & 0.717 \\
0.0762 & 0.368 & 0.716 \\
0.0762 & 0.521 & 0.713 \\
0.1524 & 0.711 & 0.717 \\
0.159 & 1.70 & 0.735 \\
0.3175 & 1.94 & 0.731 \\
\hline
\end{tabular}

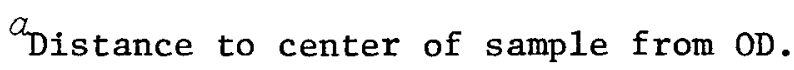


Table A.8. Radial distribution of ${ }^{14} \mathrm{C}$ in E11-07 spine at compact 28

\begin{tabular}{ccc}
\hline $\begin{array}{c}\text { Thickness of sample } \\
(\mathrm{cm})\end{array}$ & $\begin{array}{c}\text { Radius } \\
(\mathrm{cm})\end{array}$ & $\begin{array}{c}{ }^{2} \mathrm{C} \\
\text { concentration } \\
(\mu \mathrm{Ci} / \mathrm{g})\end{array}$ \\
\hline 0.0203 & 0.0102 & 2.22 \\
0.0381 & 0.0394 & 0.372 \\
0.0381 & 0.0775 & 0.324 \\
0.0762 & 0.135 & 0.335 \\
0.0762 & 0.211 & 0.320 \\
0.0762 & 0.363 & 0.359 \\
0.0762 & 0.516 & 0.363 \\
0.0762 & 0.668 & 0.347 \\
0.0711 & 0.818 & 0.368 \\
0.159 & 1.718 & 0.360 \\
0.318 & 1.956 & 0.392 \\
\hline
\end{tabular}

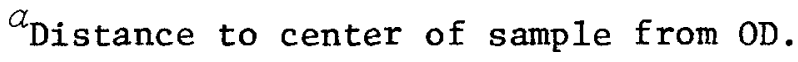

Table A.9. Radial distribution of ${ }^{14} \mathrm{C}$ in E14-01 sleeve at compact 7

\begin{tabular}{clc}
\hline $\begin{array}{c}\text { Thickness of sample } \\
(\mathrm{cm})\end{array}$ & $\begin{array}{c}\text { Radius } \\
(\mathrm{cm})\end{array}$ & $\begin{array}{c}{ }^{14} \mathrm{C} \\
\text { concentration } \\
(\mu \mathrm{Ci} / \mathrm{g})\end{array}$ \\
\hline 0.0127 & 0.0064 & 0.45 \\
0.0127 & 0.019 & 0.46 \\
0.0127 & 0.032 & 0.38 \\
0.0254 & 0.051 & 0.30 \\
0.0762 & 0.14 & 0.25 \\
0.0762 & 0.29 & 0.24 \\
0.0762 & 0.45 & 0.24 \\
0.0762 & 0.60 & 0.25 \\
0.0762 & 0.75 & 0.26 \\
0.0381 & 0.88 & 0.26 \\
0.0178 & 0.95 & 1.81 \\
\hline
\end{tabular}

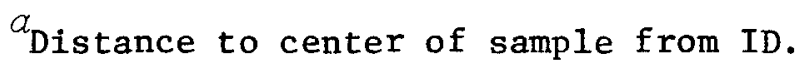


Table A.10. Radial distribution of ${ }^{14} \mathrm{C}$ in E14-01 sleeve at compact 23

\begin{tabular}{clc}
\hline $\begin{array}{c}\text { Thickness of sample } \\
(\mathrm{cm})\end{array}$ & $\begin{array}{c}\text { Radius } \\
(\mathrm{cm})\end{array}$ & $\begin{array}{c}{ }^{\alpha} \mathrm{C} \\
(\mu \mathrm{C} i / \mathrm{g})\end{array}$ \\
\hline 0.0127 & 0.0064 & 0.28 \\
0.0127 & 0.032 & 0.29 \\
0.0254 & 0.051 & 0.24 \\
0.0762 & 0.14 & 0.23 \\
0.0762 & 0.29 & 0.23 \\
0.0762 & 0.45 & 0.23 \\
0.0762 & 0.60 & 0.20 \\
0.0762 & 0.75 & 0.19 \\
0.0381 & 0.88 & 0.24 \\
0.0152 & 0.95 & 2.05 \\
\hline
\end{tabular}

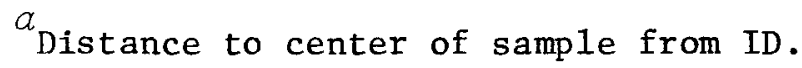

Table A.11. Radial distribution of ${ }^{14} \mathrm{C}$ in E14-01 sleeve at compact 28

\begin{tabular}{ccc}
\hline $\begin{array}{c}\text { Thickness of sample } \\
(\mathrm{cm})\end{array}$ & $\begin{array}{c}\text { Radius }^{a} \\
(\mathrm{~cm})\end{array}$ & $\begin{array}{c}{ }^{14} \mathrm{C} \text { concentration } \\
(\mu \mathrm{Ci} / \mathrm{g})\end{array}$ \\
\hline 0.0127 & 0.0191 & 0.348 \\
0.0127 & 0.0318 & 0.184 \\
0.0254 & 0.0508 & 0.166 \\
0.0686 & 0.136 & 0.149 \\
0.0762 & 0.285 & 0.146 \\
0.1524 & 0.399 & 0.123 \\
0.1524 & 0.551 & 0.152 \\
0.0762 & 0.742 & 0.149 \\
0.0381 & 0.875 & 0.153 \\
0.0127 & 0.939 & 0.695 \\
\hline
\end{tabular}

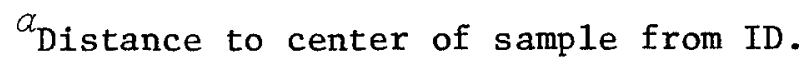


Table A.12. Radial distribution of ${ }^{14} \mathrm{C}$ in E14-01 spine at compact 23

\begin{tabular}{ccc}
\hline $\begin{array}{c}\text { Thickness of sample } \\
(\mathrm{cm})\end{array}$ & $\begin{array}{c}\text { Radius }^{a} \\
(\mathrm{~cm})\end{array}$ & $\begin{array}{c}{ }^{14} \mathrm{C} \text { concentration } \\
(\mu \mathrm{Ci} / \mathrm{g})\end{array}$ \\
\hline 0.0127 & 0.0064 & 2.11 \\
0.0254 & 0.0254 & 0.549 \\
0.0254 & 0.050 & 0.345 \\
0.0381 & 0.083 & 0.349 \\
0.381 & 0.120 & 0.333 \\
0.0762 & 0.254 & 0.319 \\
0.0762 & 0.41 & 0.339 \\
0.0762 & 0.56 & 0.322 \\
0.0762 & 0.71 & 0.453 \\
0.0762 & 0.86 & 0.311 \\
0.0889 & 0.95 & 0.351 \\
\hline$a_{\text {Distance to center of sample from oD. }}$
\end{tabular}

Table A.13. Radial distribution of ${ }^{14} \mathrm{C}$ in $\mathrm{E} 14-01$ spine at compact 28

\begin{tabular}{clc}
\hline $\begin{array}{c}\text { Thickness of sample } \\
(\mathrm{cm})\end{array}$ & $\begin{array}{c}\text { Radius } \\
(\mathrm{cm})\end{array}$ & $\begin{array}{c}1{ }^{4} \mathrm{C} \text { concentration } \\
(\mu \mathrm{C} 1 / \mathrm{g})\end{array}$ \\
\hline 0.0254 & 0.025 & 0.481 \\
0.0254 & 0.051 & 0.303 \\
0.0381 & 0.083 & 0.273 \\
0.0381 & 0.12 & 0.250 \\
0.0762 & 0.254 & 0.266 \\
0.0762 & 0.41 & 0.254 \\
0.0762 & 0.56 & 0.259 \\
0.0762 & 0.71 & 0.254 \\
0.0762 & 0.86 & 0.263 \\
0.0889 & 0.95 & 0.394 \\
\hline
\end{tabular}

Distance to center of sample from $O D$. 
Table A.14. Radial distribution of ${ }^{14} \mathrm{C}$ in F03-01 sleeve at compact 5

\begin{tabular}{ccc}
\hline $\begin{array}{c}\text { Thickness of sample } \\
(\mathrm{cm})\end{array}$ & $\begin{array}{c}\text { Radius } \\
(\mathrm{cm})\end{array}$ & $\begin{array}{c}{ }^{14} \mathrm{C} \text { concentration } \\
(\mu \mathrm{Ci} / \mathrm{g})\end{array}$ \\
\hline 0.025 & 0.013 & 0.48 \\
0.025 & 0.038 & 0.34 \\
0.046 & 0.074 & 0.27 \\
0.038 & 0.154 & 0.27 \\
0.076 & 0.287 & 0.23 \\
0.076 & 0.363 & 0.27 \\
0.076 & 0.516 & 0.27 \\
0.076 & 0.744 & 0.26 \\
0.038 & 0.87 & 0.24 \\
0.025 & 0.94 & 0.66 \\
\hline
\end{tabular}

$a_{\text {Distance to center of sample from ID. }}$

Table A.15. Radial distribution of ${ }^{14} \mathrm{C}$ in F03-01 sleeve at compact 12

\begin{tabular}{ccc}
\hline $\begin{array}{c}\text { Thickness of sample } \\
(\mathrm{cm})\end{array}$ & $\begin{array}{c}\text { Radius }^{\alpha} \\
(\mathrm{cm})\end{array}$ & $\begin{array}{c}{ }^{14} \mathrm{C} \\
\text { concentration } \\
(\mu \mathrm{Ci} / \mathrm{g})\end{array}$ \\
\hline 0.013 & 0.006 & 0.97 \\
0.025 & 0.025 & 0.64 \\
0.025 & 0.076 & 0.46 \\
0.076 & 0.165 & 0.36 \\
0.076 & 0.32 & 0.40 \\
0.076 & 0.47 & 0.39 \\
0.076 & 0.62 & 0.34 \\
0.076 & 0.77 & 0.32 \\
0.038 & 0.90 & 0.33 \\
0.025 & 0.94 & 1.02 \\
\hline
\end{tabular}

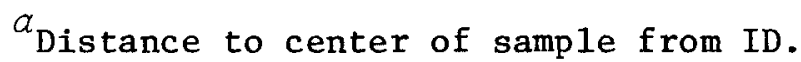


Table A.16. Radial distribution of ${ }^{14} \mathrm{C}$ in F03-01 sleeve at compact 18

\begin{tabular}{ccc}
\hline $\begin{array}{c}\text { Thickness of samp1e } \\
(\mathrm{cm})\end{array}$ & $\begin{array}{c}\text { Radius } \\
(\mathrm{cm})\end{array}$ & $\begin{array}{c}{ }^{14} \mathrm{C} \text { concentration } \\
(\mu \mathrm{Ci} / \mathrm{g})\end{array}$ \\
\hline 0.038 & 0.019 & 0.52 \\
0.038 & 0.057 & 0.41 \\
0.076 & 0.114 & 0.42 \\
0.076 & 0.27 & 0.30 \\
0.076 & 0.42 & 0.35 \\
0.076 & 0.57 & 0.37 \\
0.076 & 0.72 & 0.35 \\
0.038 & 0.86 & 0.34 \\
\hline
\end{tabular}

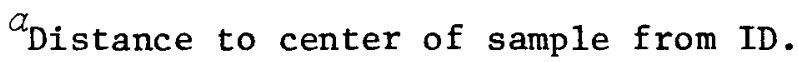

Table A.17. Radial distribution of ${ }^{14} \mathrm{C}$ in F03-01 sleeve at compact 28

\begin{tabular}{ccc}
\hline $\begin{array}{c}\text { Thickness of sample } \\
(\mathrm{cm})\end{array}$ & $\begin{array}{c}\text { Radius }^{\alpha} \\
(\mathrm{cm})\end{array}$ & $\begin{array}{c}{ }^{14} \mathrm{C} \text { concentration } \\
(\mu \mathrm{Ci} / \mathrm{g})\end{array}$ \\
\hline 0.038 & 0.057 & 0.31 \\
0.076 & 0.152 & 0.22 \\
0.076 & 0.30 & 0.21 \\
0.076 & 0.46 & 0.21 \\
0.076 & 0.61 & 0.21 \\
0.076 & 0.76 & 0.21 \\
0.038 & 0.89 & 0.21 \\
0.038 & 0.94 & 0.53 \\
\hline
\end{tabular}

${ }^{a}$ Distance to center of sample from ID. 
Table A.18. Radial distribution of ${ }^{14} \mathrm{C}$ in F03-01 spine at compact 5

\begin{tabular}{ccc}
\hline $\begin{array}{c}\text { Thickness of sample } \\
(\mathrm{cm})\end{array}$ & $\begin{array}{c}\operatorname{Radius}^{\alpha} \\
(\mathrm{cm})\end{array}$ & $\begin{array}{c}{ }^{14} \mathrm{C} \\
\text { concentration } \\
(\mu \mathrm{Ci} / \mathrm{g})\end{array}$ \\
\hline 0.013 & 0.0064 & 2.04 \\
0.038 & 0.032 & 0.83 \\
0.076 & 0.089 & 0.73 \\
0.076 & 0.165 & 0.72 \\
0.076 & 0.241 & 0.69 \\
0.076 & 0.394 & 0.69 \\
0.076 & 0.546 & 0.71 \\
0.076 & 0.699 & 0.68 \\
0.152 & 0.889 & 0.74 \\
0.159 & 1.62 & 0.79 \\
0.318 & 1.86 & 0.73 \\
\hline
\end{tabular}

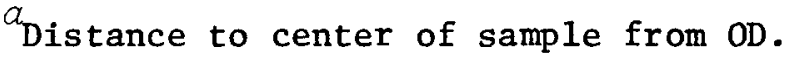

Table A.19. Radial distribution of ${ }^{14} \mathrm{C}$ in F03-01 spine at compact 12

\begin{tabular}{clc}
\hline $\begin{array}{c}\text { Thickness of sample } \\
(\mathrm{cm})\end{array}$ & $\begin{array}{c}\text { Radius }^{\alpha} \\
(\mathrm{cm})\end{array}$ & $\begin{array}{c}{ }^{14} \mathrm{C} \text { concentration } \\
(\mu \mathrm{Ci} / \mathrm{g})\end{array}$ \\
\hline 0.018 & 0.0089 & 2.25 \\
0.038 & 0.037 & 0.899 \\
0.076 & 0.094 & 0.787 \\
0.076 & 0.170 & 0.865 \\
0.076 & 0.246 & 0.881 \\
0.076 & 0.400 & 0.873 \\
0.076 & 0.551 & 0.940 \\
0.076 & 0.704 & 0.955 \\
0.152 & 0.894 & 0.850 \\
0.159 & 1.62 & 0.912 \\
0.318 & 1.86 & 0.892 \\
\hline
\end{tabular}

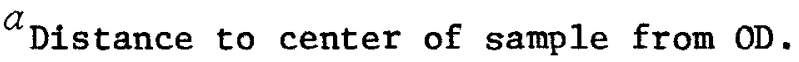


Table A.20. Radial distribution of ${ }^{14} \mathrm{C}$ in F03-01 spine at compact 18

\begin{tabular}{clc}
\hline $\begin{array}{c}\text { Thickness of sample } \\
(\mathrm{cm})\end{array}$ & $\begin{array}{c}\text { Radius } \\
(\mathrm{cm})\end{array}$ & $\begin{array}{c}{ }^{14} \mathrm{C} \\
\text { concentration } \\
(\mu \mathrm{Ci} / \mathrm{g})\end{array}$ \\
\hline 0.015 & 0.0076 & 7.44 \\
0.038 & 0.034 & 0.95 \\
0.076 & 0.091 & 0.79 \\
0.076 & 0.168 & 0.81 \\
0.076 & 0.244 & 0.80 \\
0.076 & 0.396 & 0.73 \\
0.076 & 0.549 & 0.78 \\
0.076 & 0.710 & 0.75 \\
0.152 & 0.892 & 0.88 \\
0.158 & 1.7 & 0.84 \\
0.317 & 1.94 & 0.86 \\
\hline
\end{tabular}

${ }^{a}$ Distance to center of sample from $O D$.

Table A.21. Radial distribution of ${ }^{14} \mathrm{C}$ in F03-01 spine at compact 28

\begin{tabular}{ccc}
\hline $\begin{array}{c}\text { Thickness of sample } \\
(\mathrm{cm})\end{array}$ & $\begin{array}{c}\text { Radius } \\
(\mathrm{cm})\end{array}$ & $\begin{array}{c}{ }^{14} \mathrm{C} \\
\text { concentration } \\
(\mu \mathrm{Ci} / \mathrm{g})\end{array}$ \\
\hline 0.015 & 0.0076 & 6.04 \\
0.038 & 0.0343 & 1.03 \\
0.076 & 0.0914 & 0.54 \\
0.076 & 0.168 & 0.52 \\
0.076 & 0.244 & 0.56 \\
0.076 & 0.396 & 0.65 \\
0.076 & 0.549 & 0.53 \\
0.076 & 0.701 & 0.59 \\
0.152 & 0.892 & 0.64 \\
0.158 & 1.70 & 0.52 \\
0.317 & 1.94 & 0.54 \\
\hline
\end{tabular}

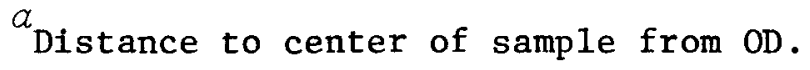


Table A.22. Radial distribution of ${ }^{14} \mathrm{C}$ in E01-01 sleeve at compact 4

\begin{tabular}{clc}
\hline $\begin{array}{c}\text { Thickness of sample } \\
(\mathrm{cm})\end{array}$ & $\begin{array}{c}\text { Radius }^{a} \\
(\mathrm{~cm})\end{array}$ & $\begin{array}{c}{ }^{14} \mathrm{C} \text { concentration } \\
(\mu \mathrm{Ci} / \mathrm{g})\end{array}$ \\
\hline 0.051 & 0.026 & 0.50 \\
0.051 & 0.066 & 0.22 \\
0.076 & 0.12 & 0.22 \\
0.076 & 0.272 & 0.23 \\
0.076 & 0.424 & 0.22 \\
0.076 & 0.576 & 0.20 \\
0.076 & 0.728 & 0.22 \\
0.051 & 0.88 & 0.22 \\
0.008 & 0.96 & 1.71 \\
\hline
\end{tabular}

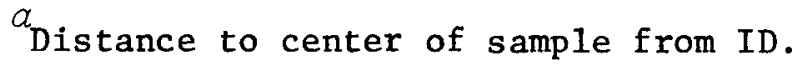

Table A.23. Radial distribution of ${ }^{14} \mathrm{C}$ in E01-01 sleeve at compact 12

\begin{tabular}{ccc}
\hline $\begin{array}{c}\text { Thickness of sample } \\
(\mathrm{cm})\end{array}$ & $\begin{array}{c}\text { Radius } \\
(\mathrm{cm})\end{array}$ & $\begin{array}{c}{ }^{14} \mathrm{C} \text { concentration } \\
(\mu \mathrm{Ci} / \mathrm{g})\end{array}$ \\
\hline 0.051 & 0.025 & 0.64 \\
0.025 & 0.064 & 0.40 \\
0.076 & 0.114 & 0.34 \\
0.076 & 0.266 & 0.32 \\
0.076 & 0.418 & 0.34 \\
0.076 & 0.57 & 0.33 \\
0.076 & 0.72 & 0.32 \\
0.038 & 0.87 & 0.34 \\
0.015 & 0.96 & 2.22 \\
\hline
\end{tabular}

Distance to center of sample from ID. 
Table A.24. Radial distribution of ${ }^{14} \mathrm{C}$ in E01-01 sleeve at compact 18

\begin{tabular}{ccc}
\hline $\begin{array}{c}\text { Thickness of sample } \\
(\mathrm{cm})\end{array}$ & $\begin{array}{c}\text { Radius } \\
(\mathrm{cm})\end{array}$ & $\begin{array}{c}{ }^{14} \mathrm{C} \\
(\mu \mathrm{Ci} / \mathrm{g})\end{array}$ \\
\hline 0.051 & 0.025 & 0.376 \\
0.076 & 0.114 & 0.294 \\
0.076 & 0.266 & 0.320 \\
0.076 & 0.418 & 0.297 \\
0.076 & 0.570 & 0.302 \\
0.076 & 0.722 & 0.319 \\
0.076 & 0.874 & 0.333 \\
0.008 & 0.960 & 2.18 \\
\hline
\end{tabular}

${ }^{a}$ Distance to center of sample from ID.

Table A.25. Radia1 distribution of ${ }^{14} \mathrm{C}$ in E01-01 sleeve at compact 28

\begin{tabular}{ccc}
\hline $\begin{array}{c}\text { Thickness of sample } \\
(\mathrm{cm})\end{array}$ & $\begin{array}{c}\text { Radius }^{\alpha} \\
(\mathrm{cm})\end{array}$ & $\begin{array}{c}{ }^{14} \mathrm{C} \text { concentration } \\
(\mu \mathrm{Ci} / \mathrm{g})\end{array}$ \\
\hline 0.051 & 0.025 & 0.36 \\
0.025 & 0.064 & 0.37 \\
0.076 & 0.114 & 0.21 \\
0.076 & 0.266 & 0.17 \\
0.076 & 0.418 & 0.18 \\
0.076 & 0.570 & 0.17 \\
0.076 & 0.722 & 0.18 \\
0.076 & 0.874 & 0.20 \\
0.020 & 0.960 & 0.66 \\
\hline
\end{tabular}

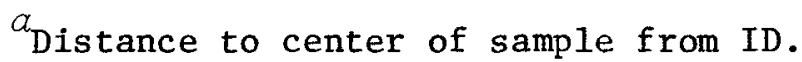


Table A.26. Radial distribution of ${ }^{14} \mathrm{C}$ in E01-01 spine at compact 23

\begin{tabular}{ccc}
\hline $\begin{array}{c}\text { Thickness of sample } \\
(\mathrm{cm})\end{array}$ & $\begin{array}{c}\text { Radius } \\
(\mathrm{cm})\end{array}$ & $\begin{array}{c}{ }^{14} \mathrm{C} \text { concentration } \\
(\mu \mathrm{Ci} / \mathrm{g})\end{array}$ \\
\hline 0.02 & 0.010 & 4.37 \\
0.038 & 0.039 & 0.65 \\
0.076 & 0.097 & 0.43 \\
0.076 & 0.173 & 0.53 \\
0.076 & 0.249 & 0.58 \\
0.076 & 0.401 & 0.56 \\
0.076 & 0.554 & 0.55 \\
0.076 & 0.706 & 0.56 \\
0.152 & 0.858 & 0.56 \\
0.159 & 1.680 & 0.48 \\
0.318 & 1.920 & 0.57 \\
\hline
\end{tabular}

${ }^{a}$ Distance to center of sample from OD.

Table A.27. Radial distribution of ${ }^{14} \mathrm{C}$ in E01-01 spine at compact 28

\begin{tabular}{ccc}
\hline $\begin{array}{c}\text { Thickness of sample } \\
(\mathrm{cm})\end{array}$ & $\begin{array}{c}\text { Radius } \\
(\mathrm{cm})\end{array}$ & $\begin{array}{c}{ }^{4} \mathrm{C} \\
\text { concentration } \\
(\mu \mathrm{Ci} / \mathrm{g})\end{array}$ \\
\hline 0.015 & 0.0075 & 5.63 \\
0.038 & 0.034 & 0.35 \\
0.076 & 0.091 & 0.43 \\
0.076 & 0.167 & 0.44 \\
0.076 & 0.243 & 0.50 \\
0.076 & 0.395 & 0.48 \\
0.076 & 0.547 & 0.44 \\
0.076 & 0.699 & 0.39 \\
0.152 & 0.889 & 0.39 \\
0.159 & 1.728 & 0.31 \\
0.318 & 1.96 & 0.43 \\
\hline
\end{tabular}

a Distance to center of sample from OD. 
Table A. 28. Radial distribution of ${ }^{14} \mathrm{C}$ in F05-05 sleeve at compact 5

\begin{tabular}{ccc}
\hline $\begin{array}{c}\text { Thickness of sample } \\
(\mathrm{cm})\end{array}$ & $\begin{array}{c}\text { Radius }^{a} \\
(\mathrm{~cm})\end{array}$ & $\begin{array}{c}{ }^{14} \mathrm{C} \text { concentration } \\
(\mu \mathrm{Ci} / \mathrm{g})\end{array}$ \\
\hline 0.064 & 0.032 & 0.31 \\
0.025 & 0.077 & 0.31 \\
0.025 & 0.102 & 0.33 \\
0.076 & 0.38 & 0.21 \\
0.076 & 0.53 & 0.21 \\
0.076 & 0.68 & 0.23 \\
0.076 & 0.84 & 0.22 \\
0.018 & 0.92 & 0.73 \\
\hline
\end{tabular}

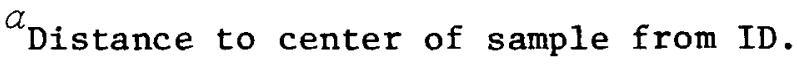

Table A.29. Radial distribution of ${ }^{14} \mathrm{C}$ in F05-05 sleeve at compact 12

\begin{tabular}{ccc}
\hline $\begin{array}{c}\text { Thickness of sample } \\
(\mathrm{cm})\end{array}$ & $\begin{array}{c}\text { Radius } \\
(\mathrm{cm})\end{array}$ & $\begin{array}{c}{ }^{14} \mathrm{C} \text { concentration } \\
(\mu \mathrm{Ci} / \mathrm{g})\end{array}$ \\
\hline 0.038 & 0.019 & 0.80 \\
0.025 & 0.089 & 0.60 \\
0.076 & 0.22 & 0.37 \\
0.076 & 0.37 & 0.36 \\
0.076 & 0.52 & 0.26 \\
0.076 & 0.67 & 0.33 \\
0.076 & 0.82 & 0.34 \\
0.025 & 0.92 & 1.12 \\
\hline
\end{tabular}

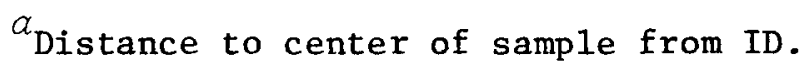


Table A. 30. Radial distribution of ${ }^{14} \mathrm{C}$ in F05-05

sleeve at compact 18

\begin{tabular}{ccc}
\hline $\begin{array}{c}\text { Thickness of sample } \\
(\mathrm{cm})\end{array}$ & $\begin{array}{c}\text { Radius }^{a} \\
(\mathrm{~cm})\end{array}$ & $\begin{array}{c}{ }^{14} \mathrm{C} \text { concentration } \\
(\mu \mathrm{Ci} / \mathrm{g})\end{array}$ \\
\hline 0.051 & 0.026 & 0.49 \\
0.025 & 0.12 & 0.48 \\
0.076 & 0.24 & 0.35 \\
0.076 & 0.39 & 0.33 \\
0.076 & 0.55 & 0.34 \\
0.076 & 0.70 & 0.33 \\
0.076 & 0.85 & 0.34 \\
\hline
\end{tabular}

${ }^{\alpha}$ Distance to center of sample from ID.

Table A.31. Radial distribution of ${ }^{14} \mathrm{C}$ in F05-05

sleeve at compact 28

\begin{tabular}{ccc}
\hline $\begin{array}{c}\text { Thickness of sample } \\
(\mathrm{cm})\end{array}$ & $\begin{array}{c}\text { Radius } \\
(\mathrm{cm})\end{array}$ & $\begin{array}{c}{ }^{14} \mathrm{C} \\
\text { concentration } \\
(\mu \mathrm{Ci} / \mathrm{g})\end{array}$ \\
\hline 0.051 & 0.026 & 0.43 \\
0.076 & 0.064 & 0.25 \\
0.076 & 0.21 & 0.21 \\
0.076 & 0.37 & 0.15 \\
0.076 & 0.52 & 0.20 \\
0.076 & 0.67 & 0.21 \\
0.076 & 0.82 & 0.21 \\
0.013 & 0.92 & 0.72 \\
\hline
\end{tabular}

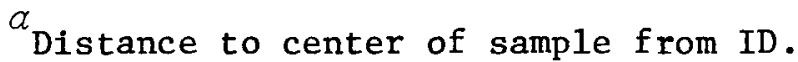


Table A.32. Radial distribution of ${ }^{14} \mathrm{C}$ in F05-05 spine at compact 5

\begin{tabular}{ccc}
\hline $\begin{array}{c}\text { Thickness of sample } \\
(\mathrm{cm})\end{array}$ & $\begin{array}{c}\text { Radius } \\
(\mathrm{cm})\end{array}$ & $\begin{array}{c}{ }^{14} \mathrm{C} \begin{array}{c}\text { concentration } \\
(\mu \mathrm{Ci} / \mathrm{g})\end{array} \\
0.013\end{array} 0^{0.007}$ \\
0.038 & 0.032 & 1.58 \\
0.076 & 0.089 & 0.56 \\
0.076 & 0.165 & 0.64 \\
0.076 & 0.24 & 0.54 \\
0.076 & 0.39 & 0.50 \\
0.076 & 0.55 & 0.65 \\
0.076 & 0.70 & 0.69 \\
0.152 & 0.89 & 0.68 \\
0.159 & 1.72 & 0.67 \\
0.318 & 1.96 & 0.67 \\
\hline
\end{tabular}

$a_{\text {Distance to center of sample from } O D .}$

Table A.33. Radia1 distribution of ${ }^{14} \mathrm{C}$ in F05-05 spine at compact 12

\begin{tabular}{ccc}
\hline $\begin{array}{c}\text { Thickness of sample } \\
(\mathrm{cm})\end{array}$ & $\begin{array}{c}\text { Radius }^{\alpha} \\
(\mathrm{cm})\end{array}$ & $\begin{array}{c}{ }^{14} \mathrm{C} \text { concentration } \\
(\mu \mathrm{Ci} / \mathrm{g})\end{array}$ \\
\hline 0.013 & 0.007 & 2.3 \\
0.038 & 0.032 & 1.1 \\
0.076 & 0.089 & 1.2 \\
0.076 & 0.24 & 1.1 \\
0.076 & 0.39 & 1.1 \\
0.076 & 0.55 & 0.90 \\
0.076 & 0.7 & 0.80 \\
0.318 & 1.96 & 1.0 \\
\hline
\end{tabular}

${ }^{a}$ Distance to center of sample from OD. 
Table A.34. Radial distribution of ${ }^{14} \mathrm{C}$ in F05-05 spine at compact 18

\begin{tabular}{ccc}
\hline $\begin{array}{c}\text { Thickness of sample } \\
(\mathrm{cm})\end{array}$ & $\begin{array}{c}\text { Radius }^{a} \\
(\mathrm{~cm})\end{array}$ & $\begin{array}{c}{ }^{14} \mathrm{C} \begin{array}{c}\text { concentration } \\
(\mu \mathrm{Ci} / \mathrm{g})\end{array} \\
0.018\end{array} 0^{0.009}$ \\
0.038 & 0.037 & 2.46 \\
0.076 & 0.094 & 0.67 \\
0.076 & 0.17 & 0.70 \\
0.076 & 0.25 & 0.57 \\
0.076 & 0.40 & 0.69 \\
0.076 & 0.55 & 0.63 \\
0.076 & 0.70 & 0.69 \\
0.152 & 0.89 & 0.73 \\
0.159 & 1.72 & 0.67 \\
0.318 & 1.96 & 0.60 \\
\hline
\end{tabular}

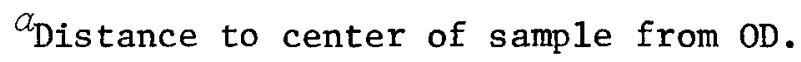

Table A.35. Radial distribution of ${ }^{14} \mathrm{C}$ in $\mathrm{F} 05-05$ spine at compact 28

\begin{tabular}{ccc}
\hline $\begin{array}{c}\text { Thickness of sample } \\
(\mathrm{cm})\end{array}$ & $\begin{array}{c}\text { Radius }^{\alpha} \\
(\mathrm{cm})\end{array}$ & $\begin{array}{c}{ }^{14} \mathrm{C} \\
\text { concentration } \\
(\mu \mathrm{Ci} / \mathrm{g})\end{array}$ \\
\hline 0.013 & 0.007 & 2.52 \\
0.038 & 0.032 & 0.22 \\
0.076 & 0.089 & 0.21 \\
0.076 & 0.17 & 0.17 \\
0.076 & 0.24 & 0.20 \\
0.076 & 0.39 & 0.20 \\
0.076 & 0.55 & 0.20 \\
0.076 & 0.70 & 0.18 \\
0.152 & 0.89 & 0.19 \\
0.159 & 1.72 & 0.18 \\
0.318 & 1.96 & 0.20 \\
\hline
\end{tabular}

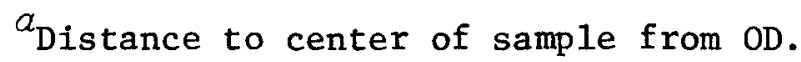




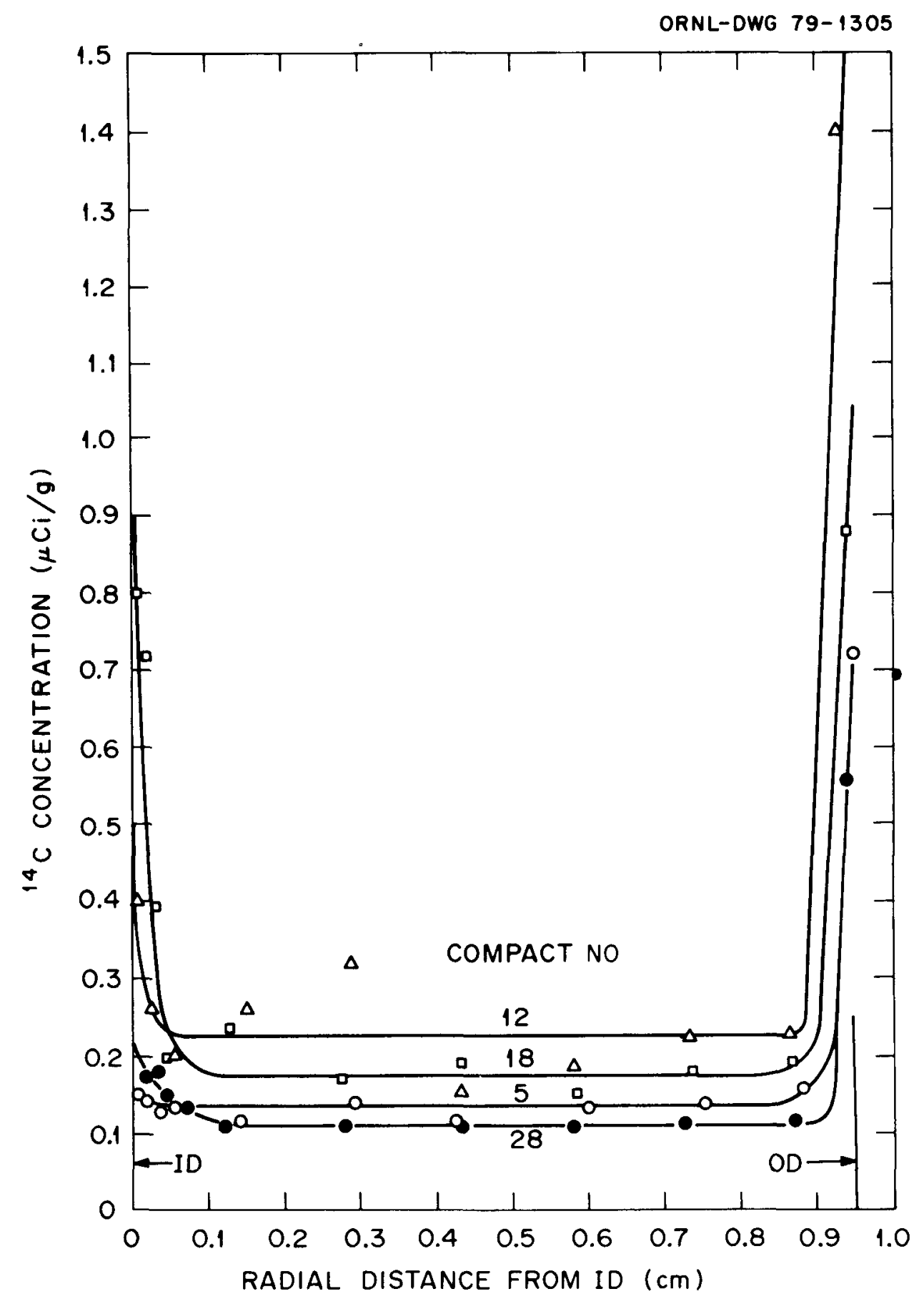

Fig. A.1. Distribution of ${ }^{14} \mathrm{C}$ in sleeve of fuel element El1-07. 


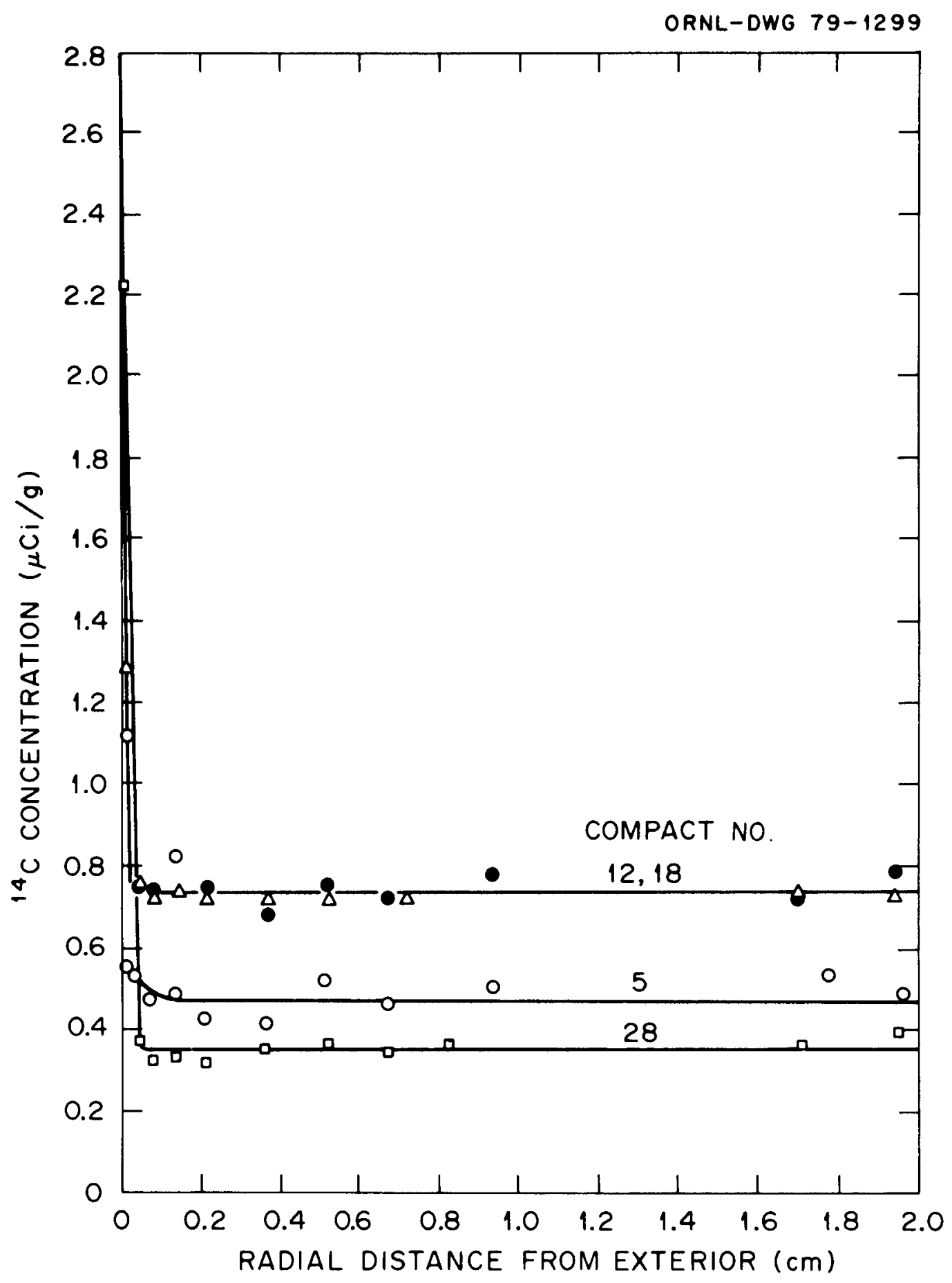

Fig. A.2. Distribution of ${ }^{14} \mathrm{C}$ in spine of fuel element E11-07. 


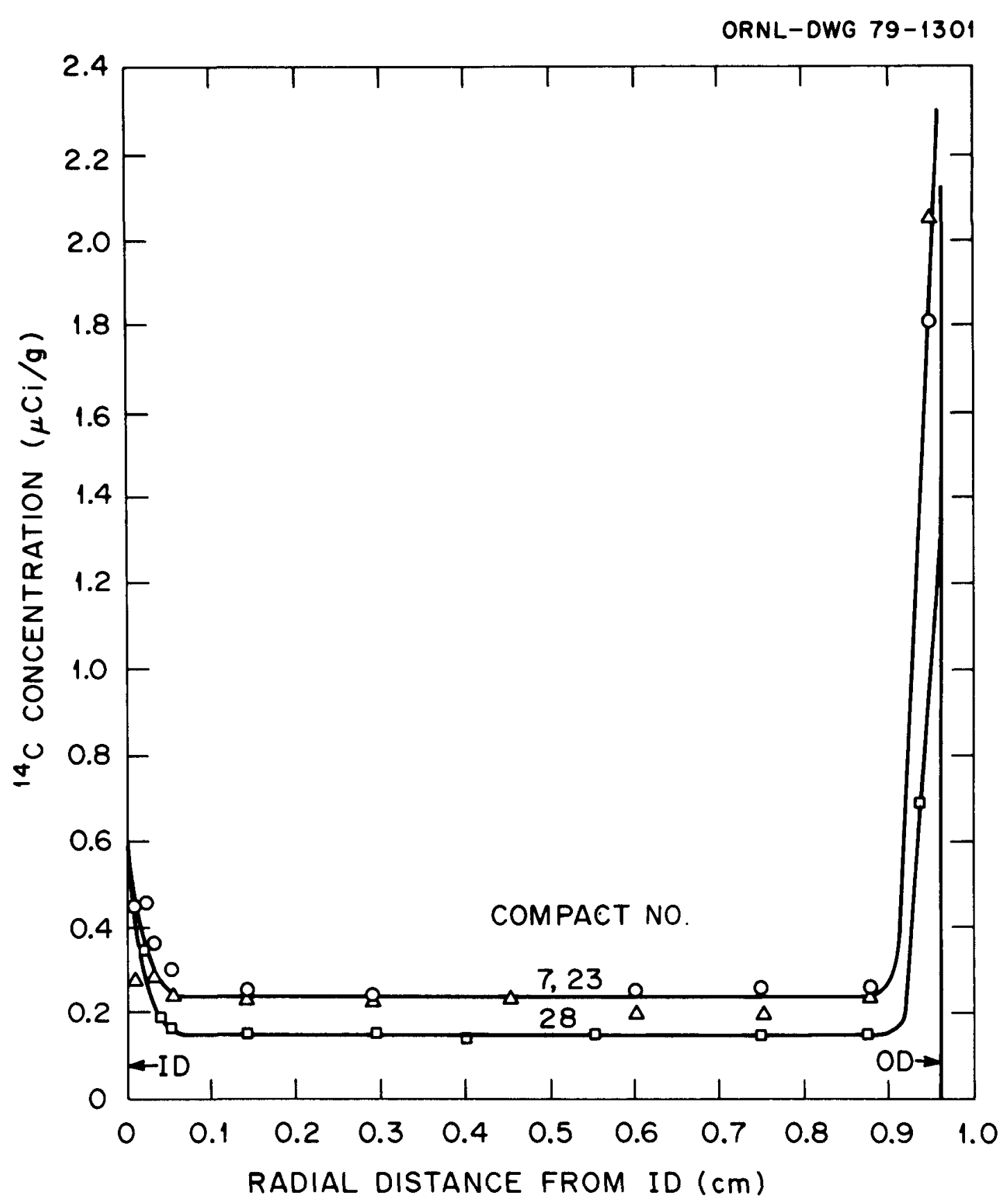

Fig. A.3. Distribution of ${ }^{14} \mathrm{C}$ in sleeve of fuel element E14-01. 


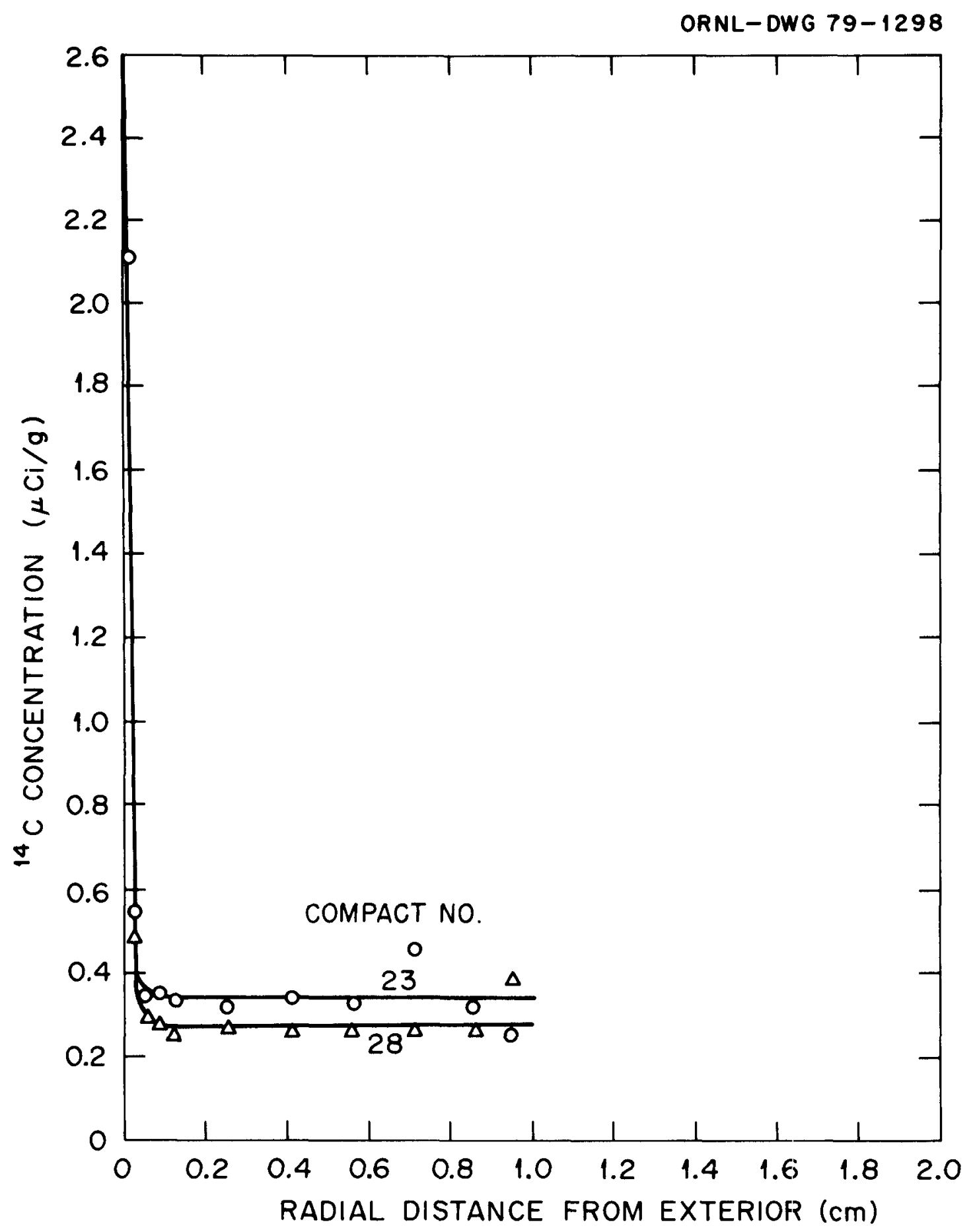

Fig. A.4. Distribution of ${ }^{14} \mathrm{C}$ in spine of fuel element E14-01. 


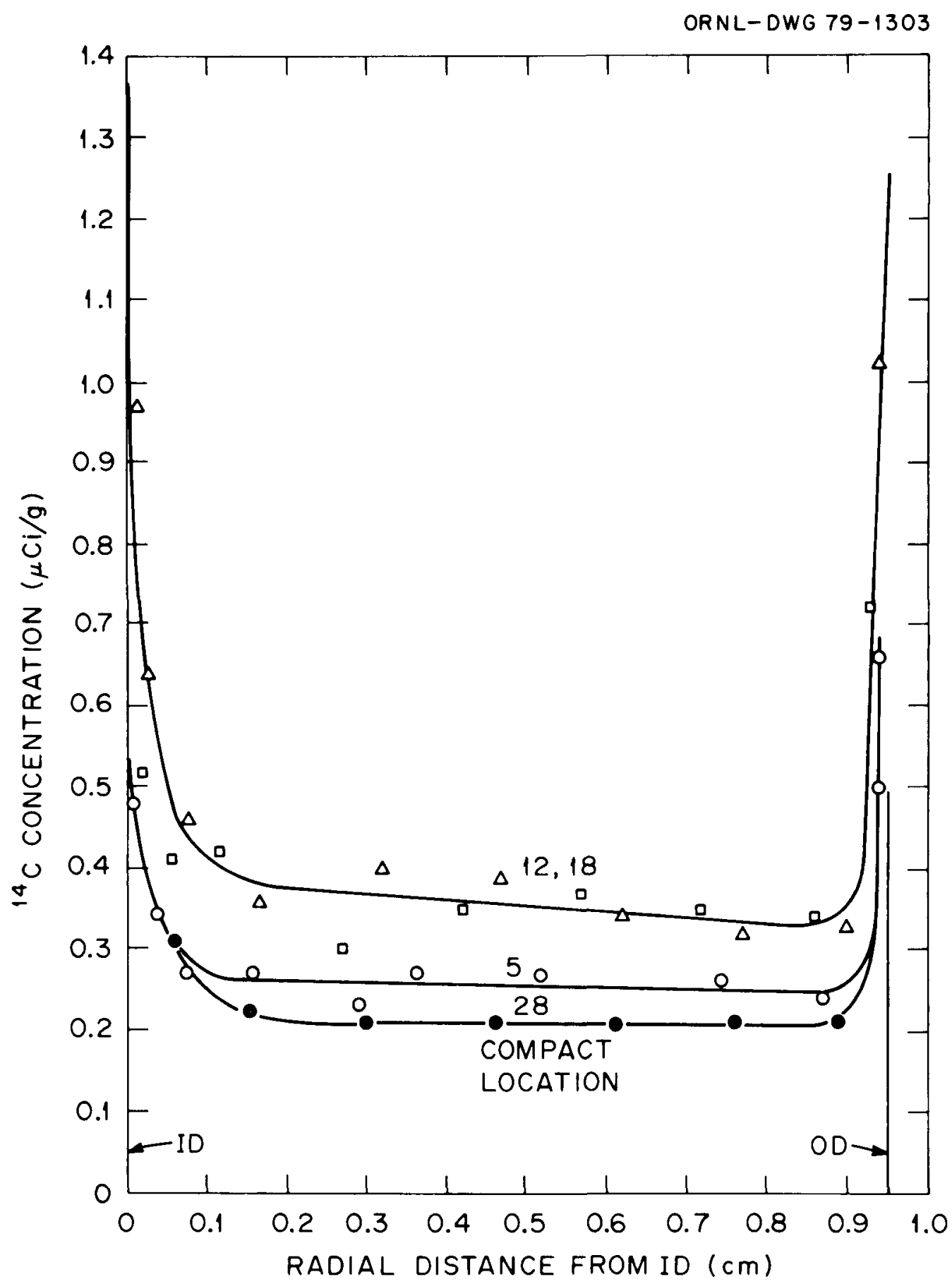

Fig. A.5. Distribution of ${ }^{14} \mathrm{C}$ in sleeve of fuel element F03-01. 


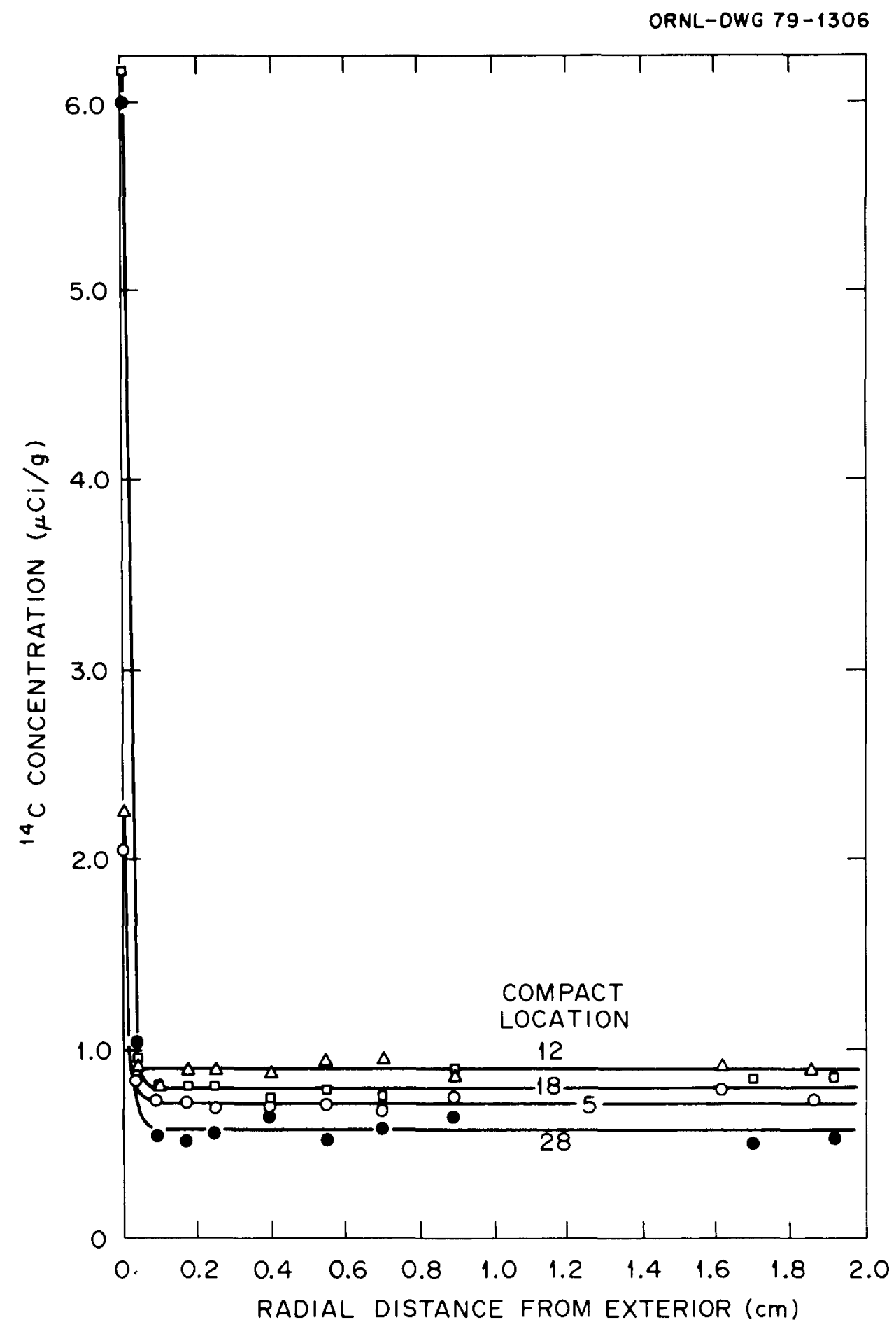

Fig. A.6. Distribution of ${ }^{14} \mathrm{C}$ in spine of fuel element F03-01. 


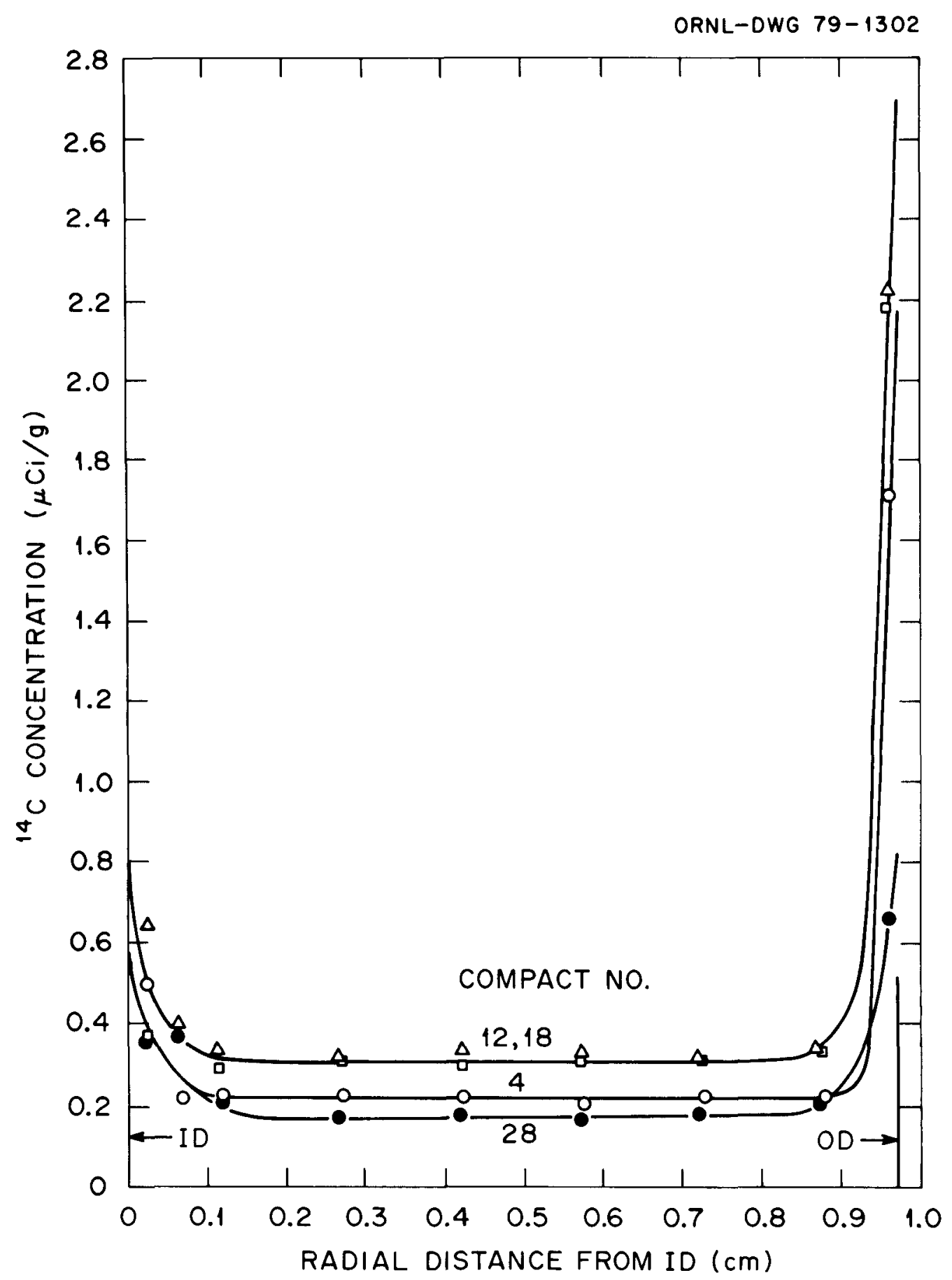

Fig. A.7. Distribution of ${ }^{14} \mathrm{C}$ in sleeve of fuel element E01-01. 


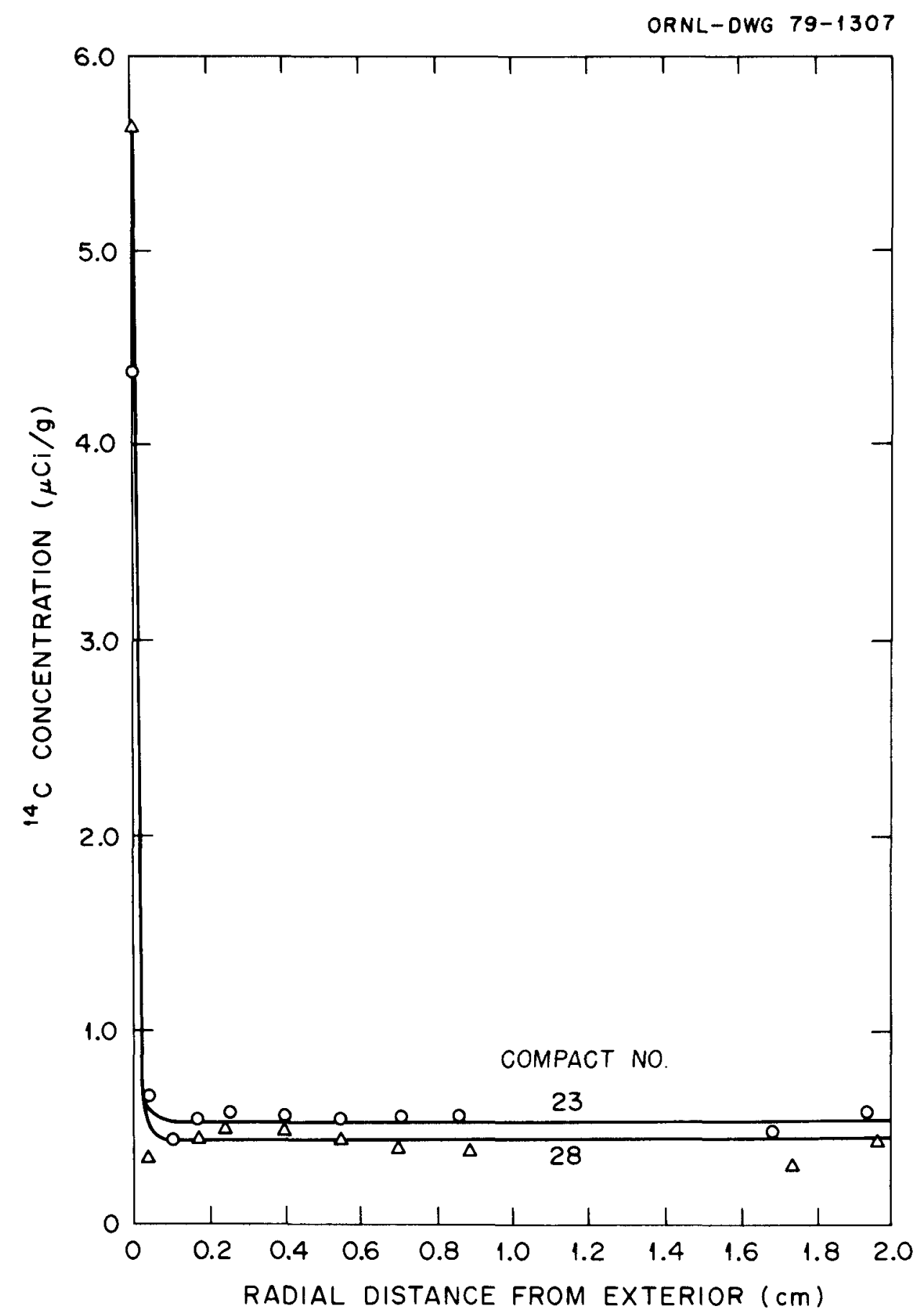

Fig. A.8. Distribution of ${ }^{14} \mathrm{C}$ in spine of fuel element E01-01. 


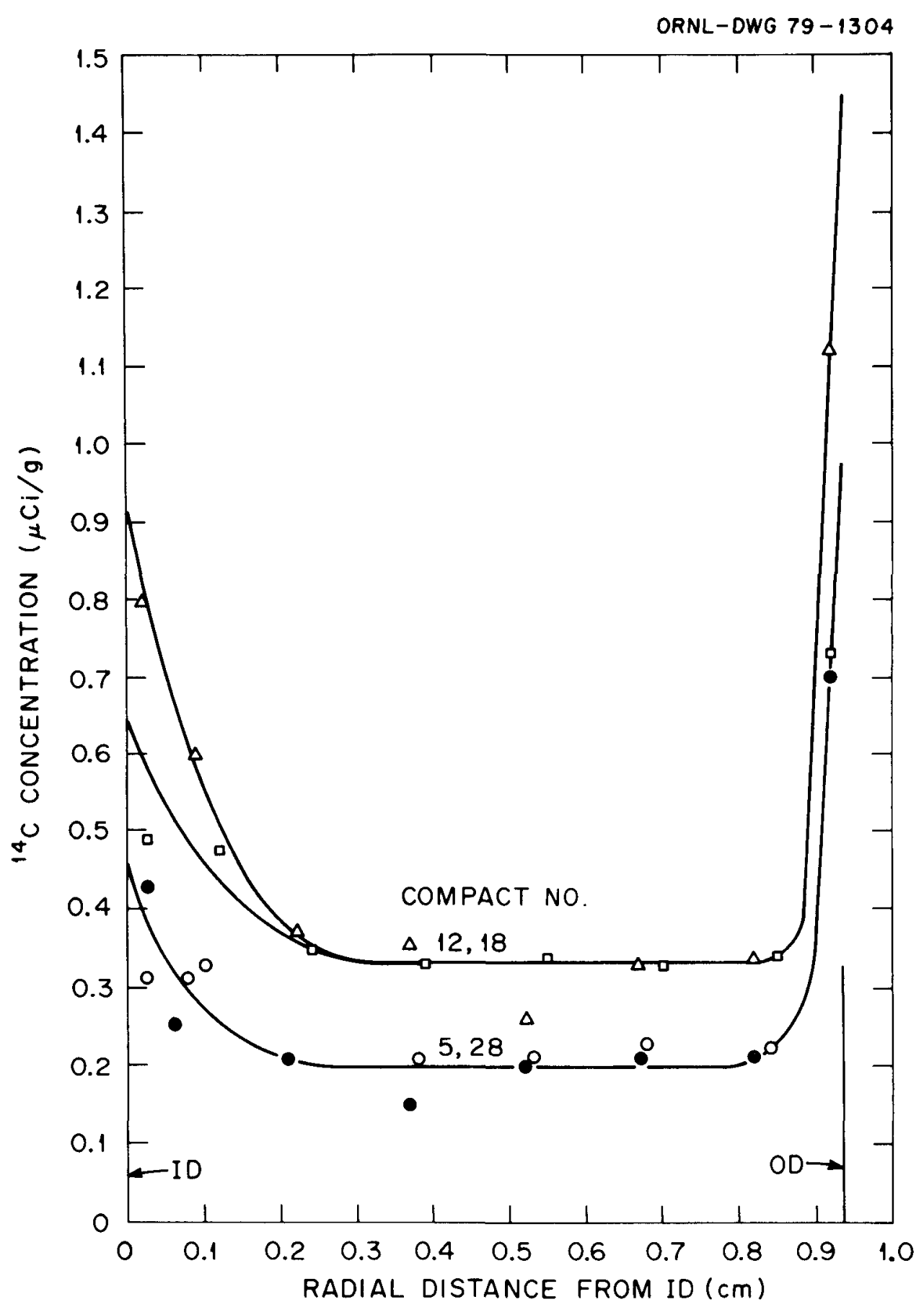

Fig. A.9. Distribution of ${ }^{14} \mathrm{C}$ in sleeve of fuel element F05-05. 


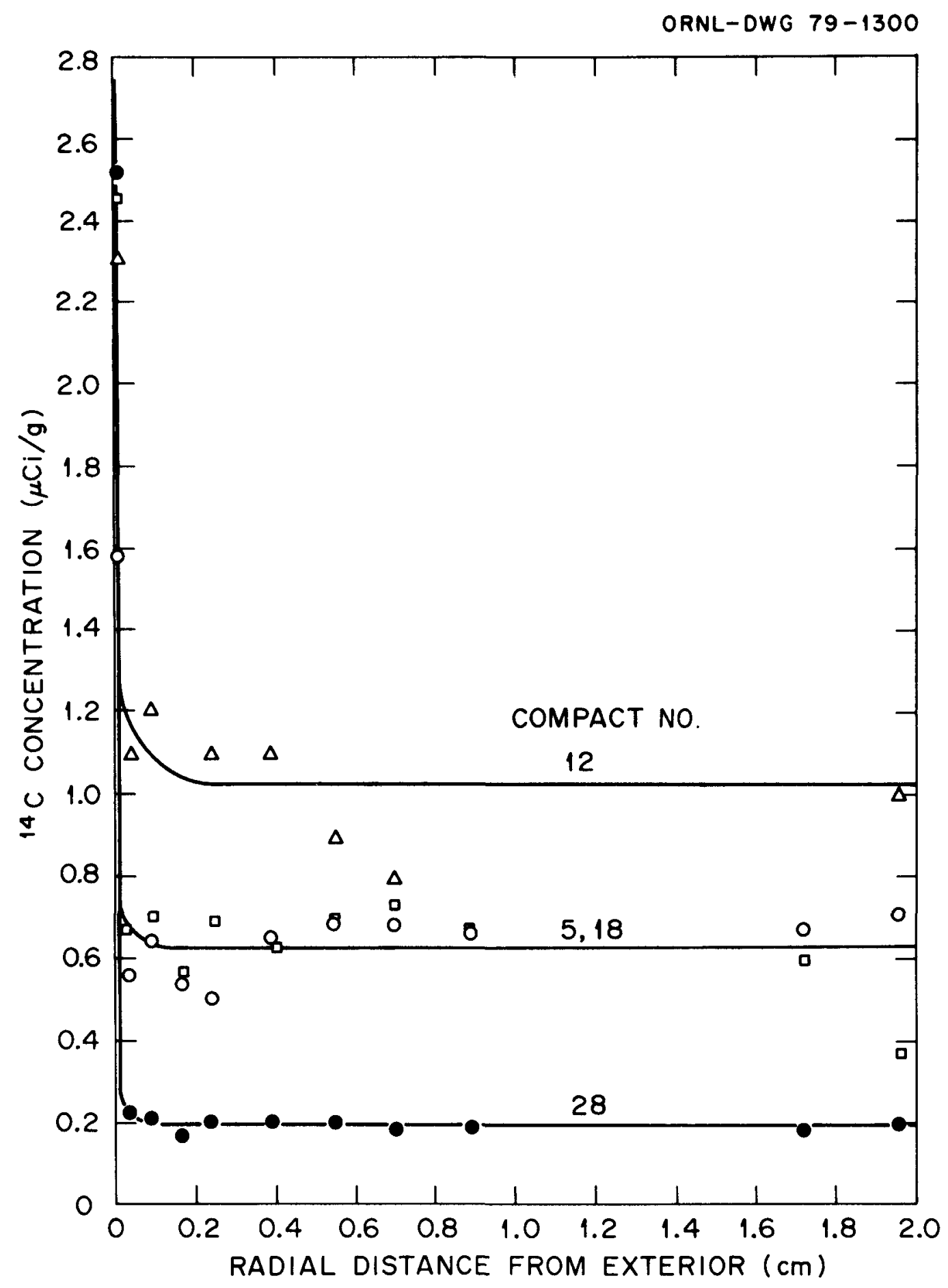

Fig. A.10. Distribution of ${ }^{14} \mathrm{C}$ in spine of fuel element F05-05. 
ORNL- 5597

Dist. Category UC-77

INTERNAL DISTRIBUTION

$\begin{aligned} \text { 1. } & \text { W. D. Burch } \\ 2 . & \text { W. Davis, Jr. } \\ 3-8 . & \text { F. F. Dyer } \\ 9 . & \text { A. L. Harkey } \\ 10 . & \text { F. J. Homan } \\ 11-20 . & \text { P. R. Kasten } \\ 21 . & \text { W. J. Lackey } \\ 22 . & \text { R. E. Leuze } \\ 23 . & \text { E. L. Long, Jr. } \\ 24 . & \text { R. A. Lorenz } \\ 25 . & \text { A. P. Malinauskas } \\ 26 . & \text { K. J. Notz }\end{aligned}$

1. W. D. Burch

2. W. Davis, Jr.

. F. F. Dyer

9. A. L. Harkey

20. P. R. Kasten

21. W. J. Lackey

22. R. E. Leuze

23. E. L. Long, Jr

25. A. P. Malinauskas

26. K. J. Notz
27. M. F. Osborne

28. J. P. Renier

29. D. R. Vondy

30-37. R. P. Wichner

38. G. R. Choppin (consultant)

39. W. H. Corcoran (consultant)

40-41. Laboratory Records Department

42. Laboratory Records, R.C.

43. Central Research Library

44. ORNL-Y-12 Technical Library Document Reference Section

45. ORNL Patent office

\section{EXTERNAL DISTRIBUTION}

46. Office of Assistant Manager for Energy Research and Development, DOE-ORO

47. Director, Nuclear Research and Development Division, DOE-ORO

48-49. Director, Division of Nuclear Power Development, DOE, Washington, DC 20545

50-215. Given distribution as shown in TID-4500 under UC-77, Gas Cooled Reactor Technology category (25 copies - NTIS) 